\title{
Water Content in Garnet from Eclogites: Implications for Water Cycle in Subduction Channels
}

\author{
Yiren Gou ${ }^{1}$, Qin Wang ${ }^{1, *}$, Yan $\mathrm{Li}^{1,2}$ and Richard Wirth ${ }^{2}$ \\ 1 State Key Laboratory for Mineral Deposits Research, School of Earth Sciences and Engineering, \\ Nanjing University, Nanjing 210046, China; ygou@smail.nju.edu.cn (Y.G.); liyan@smail.nju.edu.cn (Y.L.) \\ 2 GeoForschungsZentrum Potsdam, Section 3.5 Surface Geochemistry, D-14473 Potsdam, Germany; \\ richard.wirth@gfz-potsdam.de \\ * Correspondence: qwang@nju.edu.cn; Tel.: +86-25-83596887
}

Received: 21 March 2020; Accepted: 29 April 2020; Published: 30 April 2020

\begin{abstract}
Garnet from eclogites often shows very heterogenous and extremely high hydroxyl concentration. Eight eclogite samples were selected from the Sulu ultrahigh-pressure terrane and the Sumdo high-pressure metamorphic belt (Lhasa). The mean hydroxyl concentration in pyrope-rich

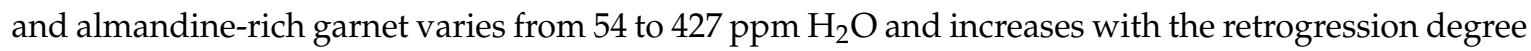
of eclogites. TEM observations reveal nanometer-sized anthophyllite exsolutions and clinochlore inclusions in water-rich domains in garnet, where anthophyllite is partly replaced by clinochlore. Because of overlapping of the infrared stretching absorption bands for structural $\mathrm{OH}$ in garnet and chlorite, it is impossible to exclude contribution of chlorite inclusions to the estimated hydroxyl concentration in garnet. The broad band near $3400 \mathrm{~cm}^{-1}$ is attributed to molecular water and nanometer-sized chlorite inclusions. Anthophyllite exsolutions may be formed by decomposition of hydrous garnet from ultrahigh-pressure eclogites during exhumation. Significant amounts of water can be stored in garnet from massif eclogites in the forms of hydroxyl in garnet and nanometer-sized inclusions of anthophyllite and clinochlore, as well as fluid inclusions. Amphibolite facies retrograde metamorphism can significantly increase both hydroxyl concentration and water heterogeneity in garnet from massif eclogites. The se nano-inclusions in garnet provide a window to trace the water cycle in subduction channels.
\end{abstract}

Keywords: water; garnet; eclogite; hydroxyl solubility; subduction channel; inclusion; infrared spectrum

\section{Introduction}

Water can widely exist in nominally anhydrous minerals (NAMs) such as olivine, pyroxene, and garnet, in the form of hydroxyl in lattice defects or molecular water in fluid inclusions (e.g., [1-6]). Subduction zones provide an important pathway to carry water into the earth's interior and play a critical role in the earth's water cycle. During subduction of the oceanic lithosphere, water released by breakdown of hydrous minerals will hydrate the mantle wedge and trigger arc volcanism, whereas subduction of the continental lithosphere is characterized by limited fluid activity and lack of coeval arc volcanism [7]. In both cases, several thousand ppm of water can be incorporated in garnet and omphacite, as evidenced by infrared (IR) spectroscopy analysis of eclogites from high-pressure (HP) and ultrahigh-pressure (UHP) metamorphic belts [8-15].

Garnet is one of the most important NAMs in the lower crust and upper mantle. Because water can remarkably decrease viscosity $[16,17]$ but enhance electrical conductivity [18] and Fe-Mg interdiffusion in garnet [19], evaluation of water content in garnet is critical for dynamic modeling and interpretation of electrical conductivity anomalies, as well as for estimation of metamorphic $P$ - $T$ conditions of HP 
and UHP rocks. The hydrous components in garnet include both structural $\mathrm{OH}$ and non-structural species, which generally can be distinguished from one another by their characteristic stretching frequencies in IR spectra [2,3]. Aqueous fluid inclusions are readily identified by their broad bands near $3400 \mathrm{~cm}^{-1}$, which have been excluded in reported water content in garnet. However, invisible inclusions of hydrous minerals in microscopically clear crystal lattice may be very difficult to separate because of the overlapping absorption bands of structural $\mathrm{OH}$ in NAMs and hydrous minerals [2]. To avoid confusion, here we use hydroxyl concentration to infer the amount of structural $\mathrm{OH}$, and the total water content for the sum of structural $\mathrm{OH}$, molecular $\mathrm{H}_{2} \mathrm{O}$ and inclusions of hydrous minerals in garnet.

Hydroxyl concentration in garnet shows wide variations from $<1$ to $>1000$ ppm $\mathrm{H}_{2} \mathrm{O}$ in eclogites from HP and UHP metamorphic belts [6,8-15], and from $<1$ to several hundred ppm $\mathrm{H}_{2} \mathrm{O}$ in kimberlite-brought peridotites, eclogites, and megacrysts [20-27]. Extremely high hydroxyl concentration in garnet was observed in UHP eclogites from Kazakhstan (up to 2500 ppm $\mathrm{H}_{2} \mathrm{O}$ ) [8] and the Dabie-Sulu orogen in eastern China (1700-2500 ppm $\mathrm{H}_{2} \mathrm{O}$ ) $[10,12,13]$, implying remarkable water capacity of garnet in subduction zones. Hydroxyl solubility in garnet is a function of pressure, temperature, water fugacity, oxygen fugacity, and chemical composition [28-30]. It is still not clear why hydroxyl concentration in garnet from UHP eclogites in Kazakhstan and the Dabie-Sulu orogen shows great variations and even exceeds the laboratory-derived hydroxyl solubility at high pressure and high temperature.

The IR spectra of eclogitic garnet often exhibit a broad band near $3400 \mathrm{~cm}^{-1}$, which has been attributed to the stretching vibration of clusters of molecular $\mathrm{H}_{2} \mathrm{O}$ in fluid inclusions $[5,6,9]$. The origin of molecular $\mathrm{H}_{2} \mathrm{O}$ in eclogitic garnet is still debated. Molecular $\mathrm{H}_{2} \mathrm{O}$ in garnet from the Dabie-Sulu eclogites is depleted in $\mathrm{D}$ relative to the structural $\mathrm{OH}$, and is regarded as intrinsic water because of a preferential loss of the D-poor molecular $\mathrm{H}_{2} \mathrm{O}$ from garnet during exhumation [6,11,12]. In contrast, for garnet from the Erzebirge and Fichtelgebirge eclogites in Germany, hydroxyl concentration is $<180$ ppm in garnet grains free of the broad band at 3400-3450 $\mathrm{cm}^{-1}$, and molecular $\mathrm{H}_{2} \mathrm{O}$ is attributed to secondary eclogite-facies fluid influx postdating the peak metamorphism [14,15]. Using the Gaussian fitting to separate absorption bands in IR spectra of NAMs, previous studies have recognized nanometer-sized inclusions of serpentine and amphibole in olivine [31,32], and clinochlore inclusions in omphacite [33]. Although fine-grained inclusions such as talc, mica, and chlorite are very common in garnet from eclogites (especially near rims and in cracks), these phases are avoided when selecting optically clean areas in garnet for IR analyses. However, transmission electron microscopy (TEM) observations found sodic amphibole exsolutions in garnet from garnet peridotites in the North Qaidam UHP metamorphic belt [34]. To our knowledge, nanometer-sized inclusions of hydrous minerals in garnet have not been systematically studied, and their influence on water content in garnet is still unknown.

This study aims to address the following questions: (1) Why does garnet from HP and UHP eclogites often show heterogeneous and extremely high hydroxyl concentration? (2) Can we find microstructural evidence to distinguish intrinsic and secondary molecular water in garnet? (3) What is the role of garnet in water cycle in subduction channels? We selected garnet from HP and UHP eclogite samples with different compositions and retrogression degrees, and then combined the Fourier transform infrared spectroscopy (FTIR) analysis with TEM observations to investigate heterogeneous water distribution in garnet from eclogites. Nanometer-sized anthophyllite exsolutions and clinochlore inclusions were found in garnet domains with high hydroxyl concentration. Based on hydrogen isotope compositions, metamorphic P-T paths and hydrogen diffusion in garnet, we discussed water capacity in garnet during subduction and exhumation.

\section{Sample Description}

To examine the influence of retrograde metamorphism and chemical composition on water content in garnet, we selected seven eclogite samples from outcrops and two boreholes of the Chinese Continental Scientific Drilling (CCSD) project at Maobei village in the Sulu UHP terrane, and a highly 
retrograded eclogite sample Y from the Sumdo HP metamorphic belt in the Lhasa terrane in Tibet (Table 1). The Sulu eclogites experienced the UHP metamorphism at 220-230 Ma because of continental collision between the Yangtze craton and the North China craton, and exhumed rapidly in a continental subduction channel [35-37]. The Sumdo eclogites show geochemistry of mid-ocean ridge basalts and record HP metamorphism under 2.6-2.7 GPa and 650-730 ${ }^{\circ} \mathrm{C}$ from 239 to $262 \mathrm{Ma}$, representing remnants of Paleo-Tethyan oceanic crust exhumed from an oceanic subduction channel [38,39]. Although phase equilibrium calculations of Sumdo eclogites yield the peak metamorphic conditions of $2.9 \mathrm{GPa}$ and $610{ }^{\circ} \mathrm{C}$, just above quartz-coesite transition boundary [40], so far UHP index minerals (e.g., coesite, diamond) have not been found in the Sumdo metamorphic belt.

Table 1. Major-element composition of garnet from the Sulu and Sumdo eclogites.

\begin{tabular}{|c|c|c|c|c|c|c|c|c|c|c|c|c|c|c|c|}
\hline Sample & Locality & Grain No. & $\mathrm{SiO}_{2}$ & $\mathrm{TiO}_{2}$ & $\mathrm{Al}_{2} \mathrm{O}_{3}$ & $\mathrm{FeO}$ & $\mathrm{MnO}$ & MgO & $\mathrm{CaO}$ & $\mathrm{Cr}_{2} \mathrm{O}_{3}$ & $\mathrm{NiO}$ & $\mathrm{Na}_{2} \mathrm{O}$ & $\mathrm{K}_{2} \mathrm{O}$ & Total & Si:12O \\
\hline \multirow[b]{2}{*}{$X$} & \multirow{2}{*}{$\begin{array}{c}\text { Maobei, } \\
\text { Sulu }\end{array}$} & 31 & 40.13 & 0.04 & 24.44 & 10.59 & 0.04 & 14.76 & 10.12 & 0.05 & 0.01 & 0.06 & 0.01 & 100.25 & 2.91 \\
\hline & & $\sigma$ & 0.27 & 0.02 & 0.23 & 0.40 & 0.01 & 0.57 & 0.71 & 0.03 & 0.01 & 0.02 & 0.01 & 0.40 & \\
\hline \multirow{2}{*}{ B295 } & \multirow{2}{*}{$\begin{array}{c}\text { CCSD-MH, } \\
547.20 \mathrm{~m}\end{array}$} & 10 & 38.14 & 0.24 & 20.64 & 24.59 & 0.18 & 4.85 & 10.96 & - & 0.03 & 0.02 & - & 99.66 & 2.98 \\
\hline & & $\sigma$ & 0.24 & 0.15 & 0.44 & 0.71 & 0.01 & 0.16 & 0.63 & - & 0.04 & 0.02 & - & 0.71 & \\
\hline \multirow{2}{*}{ MBF1 } & \multirow{2}{*}{$\begin{array}{l}\text { Maobei, } \\
\text { Sulu }\end{array}$} & 10 & 41.20 & 0.09 & 22.56 & 9.78 & 0.07 & 13.78 & 12.79 & 0.01 & 0.01 & 0.01 & - & 100.30 & 2.99 \\
\hline & & $\sigma$ & 0.17 & 0.09 & 0.23 & 0.34 & 0.01 & 0.24 & 0.33 & 0.01 & 0.01 & 0.01 & - & 0.39 & \\
\hline \multirow{2}{*}{ MBF3 } & \multirow{2}{*}{$\begin{array}{l}\text { Maobei, } \\
\text { Sulu }\end{array}$} & 10 & 41.04 & 0.11 & 22.51 & 9.01 & 0.07 & 13.84 & 13.21 & 0.03 & 0.01 & 0.01 & - & 99.83 & 2.99 \\
\hline & & $\sigma$ & 0.25 & 0.09 & 0.18 & 0.35 & 0.01 & 0.37 & 0.63 & 0.02 & 0.03 & 0.01 & - & 0.50 & \\
\hline \multirow{2}{*}{ B19 } & \multirow{2}{*}{$\begin{array}{c}\text { CCSD-PP4, } \\
51.72 \mathrm{~m}\end{array}$} & 10 & 38.14 & 0.14 & 21.01 & 26.03 & 0.26 & 4.46 & 9.39 & 0.01 & 0.01 & 0.04 & - & 99.49 & 3.00 \\
\hline & & $\sigma$ & 0.21 & 0.09 & 0.37 & 0.30 & 0.02 & 0.12 & 0.13 & 0.01 & 0.01 & 0.02 & - & 0.55 & \\
\hline \multirow{2}{*}{ B504 } & \multirow{2}{*}{$\begin{array}{c}\text { CCSD-MH, } \\
925.70 \mathrm{~m}\end{array}$} & 9 & 38.29 & 0.16 & 21.24 & 25.20 & 0.21 & 5.25 & 9.10 & 0.01 & 0.01 & 0.03 & - & 99.50 & 2.99 \\
\hline & & $\sigma$ & 0.23 & 0.06 & 0.39 & 0.36 & 0.01 & 0.12 & 0.33 & 0.01 & 0.02 & 0.02 & - & 0.53 & \\
\hline \multirow{2}{*}{ B15 } & \multirow{2}{*}{$\begin{array}{c}\text { CCSD-PP4, } \\
45.84 \mathrm{~m}\end{array}$} & 12 & 38.39 & 0.18 & 21.54 & 25.09 & 0.28 & 4.58 & 10.09 & - & 0.02 & 0.02 & - & 100.19 & 2.99 \\
\hline & & $\sigma$ & 0.17 & 0.08 & 0.12 & 0.31 & 0.01 & 0.08 & 0.13 & - & 0.02 & 0.02 & 0.01 & 0.33 & \\
\hline \multirow{2}{*}{ Y } & Sumdo, & 83 & 38.94 & 0.07 & 22.12 & 19.90 & 0.46 & 7.79 & 10.20 & 0.03 & 0.02 & 0.02 & - & 99.55 & 2.98 \\
\hline & Tibet & $\sigma$ & 0.52 & 0.05 & 0.52 & 1.13 & 0.26 & 0.87 & 0.66 & 0.03 & 0.02 & 0.02 & - & 0.66 & \\
\hline
\end{tabular}

Note: $\sigma$ is the standard error of analyzed grains. Si:12O is the number of Si atoms relative to 12 oxygen, which equals to 3 for a normal garnet.

All the samples are coarse-grained, showing garnet-rich and omphacite-rich layers and inequigranular texture (Figure 1). Samples X and B295 are fresh UHP eclogites with coarse-grained garnet and omphacite. Samples MBF1 and MBF3 are fresh garnetites with 80-90 vol.\% garnet, which were collected from a garnet-rich layer in the CCSD drilling site. The volume fractions of constituent minerals for each sample were determined by optical microscope observations of thin sections. Samples B19 and B504 are slightly retrograded eclogites with 55-60 vol.\% garnet, 30 vol.\% omphacite, 5 vol.\% quartz and 5-10 vol.\% symplectite. By contrast, retrograded UHP eclogite sample B15 consists of 40 vol.\% garnet, 25 vol.\% omphacite, 15 vol.\% symplectite, 10 vol.\% quartz, 3 vol.\% phengite, 3 vol. $\%$ rutile, 2 vol. \% biotite, and 2 vol.\% magnetite. Samples B19, B504 and B15 have been strongly deformed with the stretching lineation defined by elongated garnet and omphacite. Retrograded HP eclogite sample Y contains 50 vol.\% garnet, 30 vol.\% amphibole, 10 vol.\% quartz, 5 vol.\% phengite, and 5 vol.\% rutile (Figure 1).

Compositions of garnet were analyzed using electron microprobe JEOL JXA-8800M at Nanjing University and EPMA-1720H at Zhejiang University, Hangzhou, China. For each sample, at least nine grains were analyzed to obtain the average composition of garnet (Table 1). The composition of garnet varies slightly from grain to grain in a thin section scale, but individual garnet grains are homogenous and free of visible zoning (Figure 2). Three groups of garnet can be distinguished. For eclogite samples in the Sulu UHP terrane, garnet from samples X, MBF1 and MBF3 is pyrope-rich with composition of $\operatorname{Prp}_{50-55} \mathrm{Grs}_{27-31} \mathrm{Alm}_{15-18} \mathrm{Adr}_{0-3} \mathrm{Sps}_{0-1}$, whereas garnet from CCSD samples B15, B19, B295, and B504 is almandine-rich with composition of Alm ${ }_{50-55} \operatorname{Grs}_{24-27} \operatorname{Prp}_{18-21} \mathrm{Adr}_{1-4} \mathrm{Sps}_{0-1}$. Garnet from retrograded eclogite sample $\mathrm{Y}$ in the Sumdo metamorphic belt shows moderate Fe and $\mathrm{Mg}$ contents with composition of $\mathrm{Alm}_{41} \operatorname{Prp}_{30} \mathrm{Grs}_{27} \mathrm{Adr}_{1} \mathrm{Sps}_{1}$. Mineral abbreviations in this paper follow Whitney and Evans [41]. 

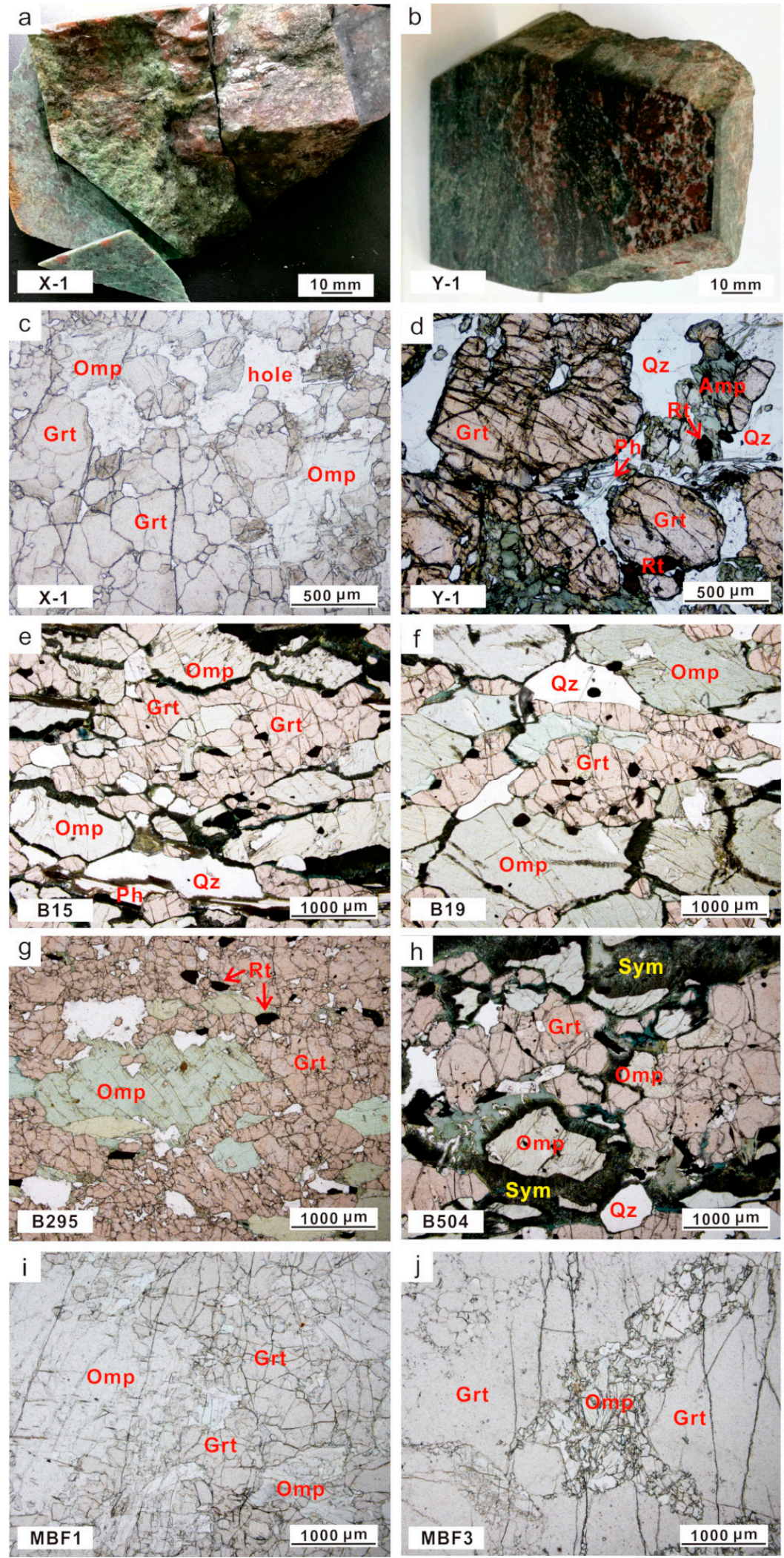

Figure 1. $(\mathbf{a}, \mathbf{b})$ Specimen and $(\mathbf{c}-\mathbf{j})$ thin sections of typical eclogite samples observed using planepolarized light. Mineral abbreviations: Grt, garnet; Omp, omphacite; Amp, amphibole; Qz, quartz; Ph, phengite; Rt, rutile; Sym, symplectite. 

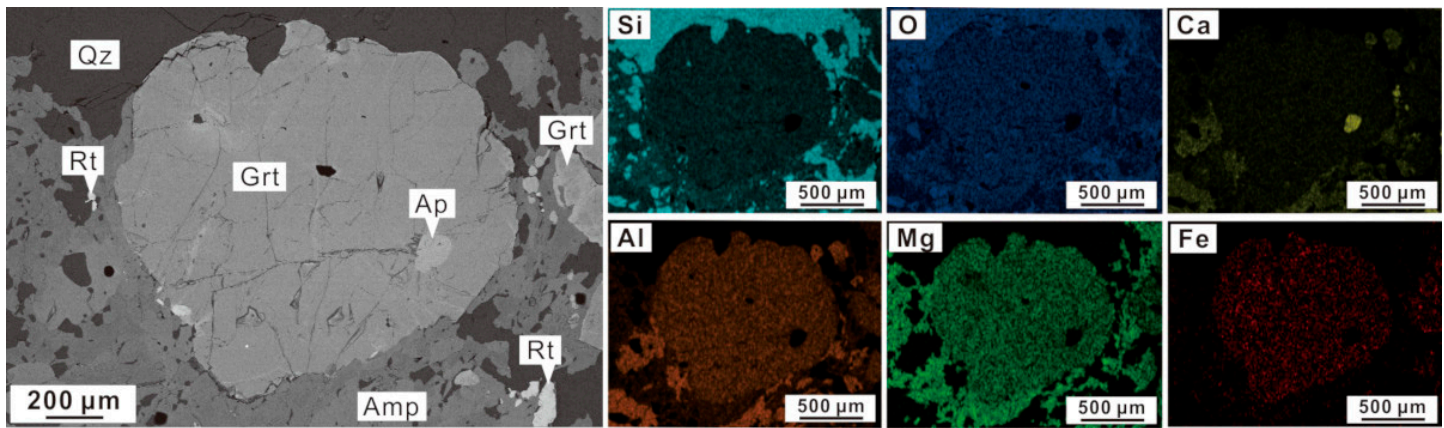

Figure 2. Energy dispersive spectrometer (EDS) mapping shows homogenous composition of garnet from retrograded eclogite Y. Grt, garnet; Amp, amphibole; Qz, quartz; Rt, rutile; Ap, apatite.

\section{Methods}

For each sample, several double polished thin sections were prepared with a thickness from 200 to $400 \mu \mathrm{m}$ for IR analysis. To constrain the grain thickness precisely, we divided each thin section into $>10$ regions, and determined the thickness of each region by averaging 3-5 measured points using the $\mathrm{SKCH}-1$ thickness gouge. The accuracy of the SKCH-1 thickness gouge is $1 \mu \mathrm{m}$. The average thickness of each region was then used for garnet grains in this region. Because of its cubic symmetry, garnet is isotropic in $\mathrm{OH}$ absorption. Following the method of Bell et al. [42], unpolarized IR absorbance spectra were collected using Bruker Vertex 70V FTIR at Nanjing University (Nanjing, China) at $25^{\circ} \mathrm{C}$ and wavenumbers $3000-3800 \mathrm{~cm}^{-1}$. Using $40 \times 40 \mu \mathrm{m}$ aperture and a $\mathrm{KBr}$ beam-splitter, optically clean areas without visible inclusions or fractures were analyzed with 128 scans and a $4 \mathrm{~cm}^{-1}$ resolution.

To calculate the integral absorbance, the baseline was subtracted from the IR absorption spectrum using an open-source software Fityk (version 0.9.8) [43] (Figure 3a). We used the Fityk 0.9.8 to fit absorption spectrum after baseline correction, and then applied Gaussian functions to separate characteristic bands based on their frequency and a full width at half maximum (FWHM) (Figure 3b). Bands with the FWHM $>20 \mathrm{~cm}^{-1}$ are inferred as broad bands, which are superimposed by narrow and weak bands with the FWHM $<20 \mathrm{~cm}^{-1}$. The combination of broad and narrow bands allows us to investigate subtle changes of the IR spectra of garnet, and to reveal the relationship between absorption bands and mineral chemistry.

Hydroxyl concentration in garnet was calculated using the Beer-Lambert law:

$$
A=\varepsilon c h,
$$

where $A$ is absorbance in $\mathrm{cm}^{-1}, \varepsilon$ is integral specific absorption coefficient and equals to $1.39 / \mathrm{ppm} / \mathrm{cm}^{2}$ for pyrope-rich garnet, $c$ is hydroxyl concentration in $\mathrm{mol} / \mathrm{L}$, and $h$ refers to the thickness of a grain [42]. Uncertainties in accuracy of structurally bound $\mathrm{OH}$ depend on: (1) absorption coefficient; (2) grain thickness; (3) baseline correction; (4) deduction of the broad band near $3400 \mathrm{~cm}^{-1}$. The difference in absorption coefficients between pyrope [42] and grossular [44] is within $10 \%$, suggesting a small compositional effect on the absorption coefficient for our garnet samples. With careful polishing and thickness measurement, the error in grain thickness is within $5 \%$. The baseline correction is realized by using spline and polyline functions embedded in Fityk 0.9 .8 with error $<10 \%$ [43]. The sum of the integral areas of $\mathrm{OH}$-absorption bands were used to calculate hydroxyl concentration in garnet. On these bases, the overall uncertainty in hydroxyl concentration in garnet is estimated to be less than $30 \%$ [10]. 

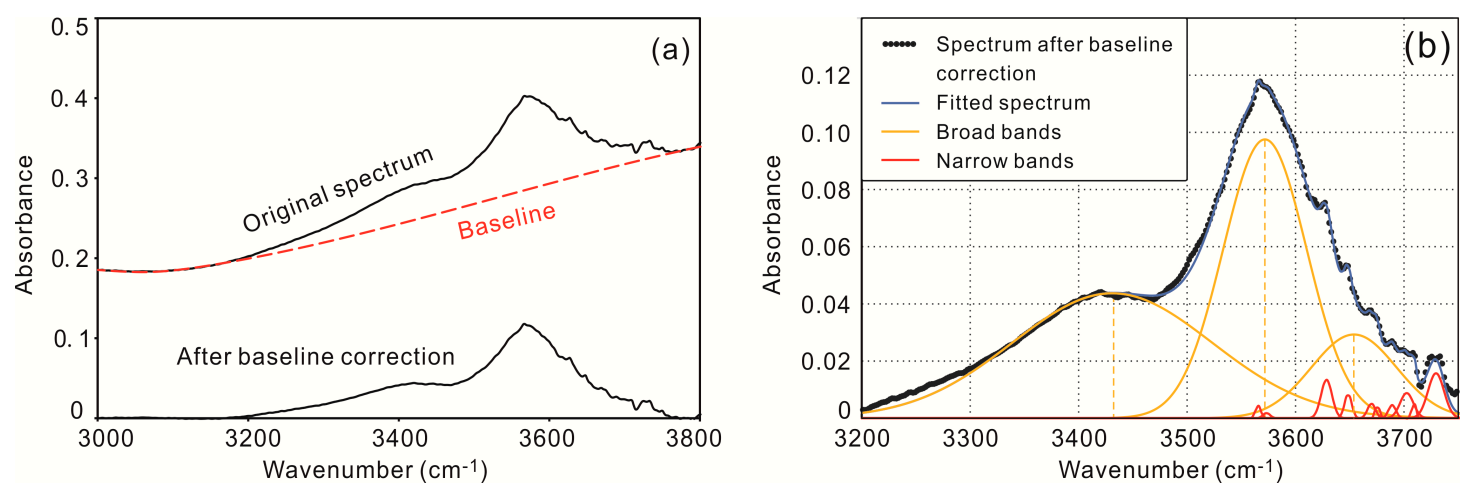

Figure 3. (a) IR spectra of garnet grain Y-4-1.7 from sample $Y$ before and after baseline correction, and (b) Gaussian fit for the spectrum after baseline correction.

Given the lack of an integral absorption coefficient for molecular $\mathrm{H}_{2} \mathrm{O}$ and the difficulty in determining the thickness of fluid inclusions, the exact amount of molecular $\mathrm{H}_{2} \mathrm{O}$ in NAMs cannot be obtained from IR spectra. If using the broad band at $3400-3450 \mathrm{~cm}^{-1}$ and the same absorption coefficient as for hydroxyl in garnet (i.e., $1.39 / \mathrm{ppm} / \mathrm{cm}^{2}$ ), the amount of molecular $\mathrm{H}_{2} \mathrm{O}$ in garnet was probably overestimated by a factor $\geq 2$ [15]. To avoid confusion, we used the integral absorbance of the broad band at $3410-3486 \mathrm{~cm}^{-1}$ to compare the intensity of molecular $\mathrm{H}_{2} \mathrm{O}$ in garnet.

Electron-transparent foils for TEM observations were prepared by focused ion beam (FIB) technique [45], utilizing a single-beam device (FEI FIB200 TEM) and a state-of-the-art dual beam system (FEI Helios) operated at German Research Center for Geosciences, Potsdam, Germany. The foil thickness is less than 100-150 nm. A TECNAI F20 X-Twin TEM (FEI Company, Hillsboro, OR, United States) was operated at $200 \mathrm{keV}$ with a Schottky emitter as the electron source, which was equipped with a Gatan imaging filter, a Fishione high-angle annular dark-field detector (HAADF), and an energy-dispersive X-ray (EDX) analyzer with an ultrathin detector window. TEM bright-field and dark-field images, as well as high-resolution lattice fringe images, were routinely acquired as energy-filtered images applying a $20 \mathrm{eV}$ window to the zero-loss peak. High-resolution images were used to calculate diffraction patterns by fast Fourier transform (FFT). EDX analyses were carried out in the STEM thus avoiding mass loss during data acquisition. Linear scans and elemental mapping were acquired using the corresponding X-ray intensities. Electron energy-loss spectroscopy (EELs) was performed with a Gatan GIF imaging filter in the diffraction mode, using a camera length of $700 \mathrm{~mm}$, and a dispersion of $0.1 \mathrm{eV} / \mathrm{channel}$. Spectra were obtained by cumulative acquisition (10-15 spectra) with an acquisition time of $0.2-1 \mathrm{~s}$ to prevent irradiation damage.

\section{Results}

\subsection{FTIR Analysis}

Consistent with previous studies [8-15], there are three groups of broad absorption bands in IR spectra of garnet: (I) $3627-3686 \mathrm{~cm}^{-1}$ band with the FWHM $<100 \mathrm{~cm}^{-1}$, (II) $3565-3603 \mathrm{~cm}^{-1}$ band with the FWHM $<100 \mathrm{~cm}^{-1}$, and (III) $3410-3486 \mathrm{~cm}^{-1}$ band with the FWHM $>160 \mathrm{~cm}^{-1}$ (Figure 3b). In addition, we distinguished 11 characteristic narrow bands and labeled them from A to K: (A) $3565-3569 \mathrm{~cm}^{-1}$; (B) $3575-3598 \mathrm{~cm}^{-1}$; (C) $3596-3608 \mathrm{~cm}^{-1}$; (D) $3611-3619 \mathrm{~cm}^{-1}$; (E) $3622-3629 \mathrm{~cm}^{-1}$; (F) $3632-3637 \mathrm{~cm}^{-1}$; (G) 3644-3648 cm $\mathrm{cm}^{-1}$; (H) 3653-3657 cm $\mathrm{cm}^{-1}$; (I) 3664-3669 cm-1; (J) 3670-3678 cm $\mathrm{cm}^{-1}$; (K) 3687-3693 cm-1. The relatively stable wavenumbers of these narrow bands in IR spectra of different samples imply their connection with hydrogen substitution mechanisms in garnet. The unstable peaks around $3710 \mathrm{~cm}^{-1}$ in some grains were caused by varying water vapor during experiments [10], which were deleted in the estimation of hydroxyl concentration.

The group I and II bands have been attributed to the vibration of $(\mathrm{OH})_{4}{ }^{4-}$ clusters in tetrahedral sites in garnet by $\mathrm{SiO}_{4}{ }^{4-} \rightarrow(\mathrm{OH})_{4}{ }^{4-}$ substitution $[9,20,46-48]$. The group III band is generally 
recognized as the vibration of clusters of molecular water in micro-inclusions $(<1-2 \mu \mathrm{m})[5,6,9-15]$. Hence the hydroxyl concentration in garnet is calculated from Equation (1) and the sum of integrated areas of the group I and II bands. As shown in Table 2, the mean hydroxyl concentration in garnet increases with the retrogression degree: from 54-113 ppm $\mathrm{H}_{2} \mathrm{O}$ in fresh eclogites (samples X, B295, MBF1, and MBF3), 124-127 ppm $\mathrm{H}_{2} \mathrm{O}$ in slightly retrograded eclogites (samples B19 and B504), to 366-427 $\mathrm{H}_{2} \mathrm{O}$ ppm in retrograded eclogites (samples B15 and Y). In each thin section, hydroxyl concentration in garnet differs from grain to grain, and does not change systemically from the core to rim (Figure S1). The maximum hydroxyl concentration in garnet grains from retrograded UHP eclogite sample B15 and retrograded HP eclogite sample $\mathrm{Y}$ reaches 635 and 1626 ppm $\mathrm{H}_{2} \mathrm{O}$, respectively. The standard deviation of hydroxyl concentration in garnet from these samples also increases with the retrogression degree of eclogites, suggesting that retrograde metamorphism can significantly enhance both water content and water heterogeneity in garnet.

Table 2. Water content in garnet from the Sulu and Sumdo eclogites.

\begin{tabular}{|c|c|c|c|c|c|c|c|c|c|}
\hline \multirow[t]{2}{*}{ Sample } & \multirow[t]{2}{*}{ Lithology } & \multicolumn{4}{|c|}{$\begin{array}{l}\text { Hydroxyl Concentration } \\
\left(\text { ppm } \mathrm{H}_{2} \mathrm{O}\right)\end{array}$} & \multicolumn{4}{|c|}{$\begin{array}{l}\text { Primary Structural Water }{ }^{1} \\
\left(\mathrm{ppm} \mathrm{H}_{2} \mathrm{O}\right)\end{array}$} \\
\hline & & $N$ & Min. & Max. & Mean & $N$ & Min. & Max. & Mean \\
\hline $\mathbf{X}$ & UHP eclogite & 47 & 0 & 356 & $113 \pm 89$ & 12 & 0 & 84 & $24 \pm 22$ \\
\hline B295 & UHP eclogite & 14 & 44 & 124 & $87 \pm 22$ & 14 & 44 & 124 & $87 \pm 22$ \\
\hline MBF1 & UHP garnetite & 11 & 33 & 168 & $66 \pm 43$ & 7 & 33 & 52 & $41 \pm 8$ \\
\hline MBF3 & UHP garnetite & 25 & 6 & 110 & $54 \pm 27$ & 17 & 13 & 89 & $46 \pm 18$ \\
\hline B19 & Slightly retrograted UHP eclogite & 26 & 32 & 511 & $127 \pm 106$ & 16 & 32 & 139 & $68 \pm 30$ \\
\hline B504 & Slightly retrograted UHP eclogite & 18 & 36 & 315 & $124 \pm 80$ & 9 & 36 & 97 & $63 \pm 18$ \\
\hline B15 & Retrograted UHP eclogite & 23 & 183 & 635 & $366 \pm 139$ & 2 & 251 & 254 & $253 \pm 3$ \\
\hline $\mathrm{Y}$ & Retrograted HP eclogite & 184 & 48 & 1626 & $427 \pm 372$ & 37 & 55 & 299 & $133 \pm 59$ \\
\hline
\end{tabular}

${ }^{1}$ Primary structural water is estimated for garnet grains without the broad $3410-3486 \mathrm{~cm}^{-1}$ band. $N$ refers to the number of analyzed grains. The standard deviations of hydroxyl concentration and primary structural water content come from the analyzed grains.

Following Schmädicke and Gose [14], the amount of primary structural water in each sample is estimated from garnet grains without the group III band. The mean value of the amount of primary structural water varies from 24 to $87 \mathrm{ppm} \mathrm{H}_{2} \mathrm{O}$ in fresh and slightly retrograded eclogites, much lower than 133-253 ppm $\mathrm{H}_{2} \mathrm{O}$ in retrograded eclogite samples B15 and Y (Table 2). In addition, although hydroxyl concentration in garnet has larger variations than primary structural water, both yield a mode of 75 ppm $\mathrm{H}_{2} \mathrm{O}$ (Figure 4). Except garnet from fresh UHP eclogite sample B295 that does not exhibit the group III band, both the mean value and the standard variation of primary structural water in garnet are smaller than those of hydroxyl concentration, implying a relationship between the group III band and hydroxyl bands in garnet. Similar with previous studies on eclogitic garnet from the Dabie Mountains [12], the sum of integral absorbance of the group I and group II bands increases with the integral absorbance of the group III band (Figure 5a).

In IR spectra of garnet from massif eclogites $[10,12,14,15]$ and kimberlite xenoliths in southern Africa [20], the group II band near $3570 \mathrm{~cm}^{-1}$ is prominent and accompanied with a less intense group I band near $3650 \mathrm{~cm}^{-1}$. However, in this study, such trend only occurs for garnet from sample Y and most garnet grains from sample $X$. The group I band is stronger than the group II band in garnet from samples MBF1, MBF3, B19, B504, and B15 (Figure 5b). Statistically, the absorbance of the group II band and the group III band shows a positive correlation for all samples, especially for garnet from retrograded HP eclogite sample Y (Figure $5 \mathrm{c}$ ). However, the positive correlation between the group I and group III bands is evident only for samples MBF1, MBF3, B19, B504, and B15 (Figure 5d).

It is worthy to note that among fresh UHP eclogite samples from the Sulu terrane, sample $X$ is characterized by largest hydroxyl concentration of $113 \pm 89 \mathrm{ppm} \mathrm{H}_{2} \mathrm{O}$, the smallest amount of primary structural water of $24 \pm 22 \mathrm{ppm} \mathrm{H}_{2} \mathrm{O}$, and weak correlation between the intensity of hydroxyl absorption bands (group I and group II bands) and the group III band (Table 2 and Figure 5). The reason will be investigated using TEM observations. 

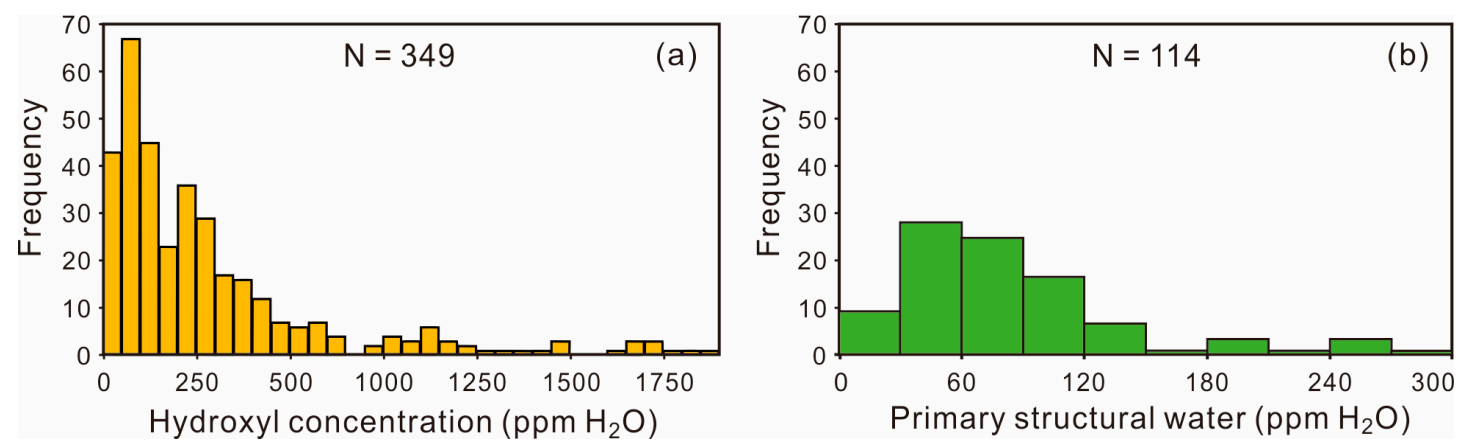

Figure 4. Histograms show the concentration range and frequency of (a) hydroxyl and (b) primary structural water in garnet from the Sulu and Sumdo eclogites. $N$ is the grain number.
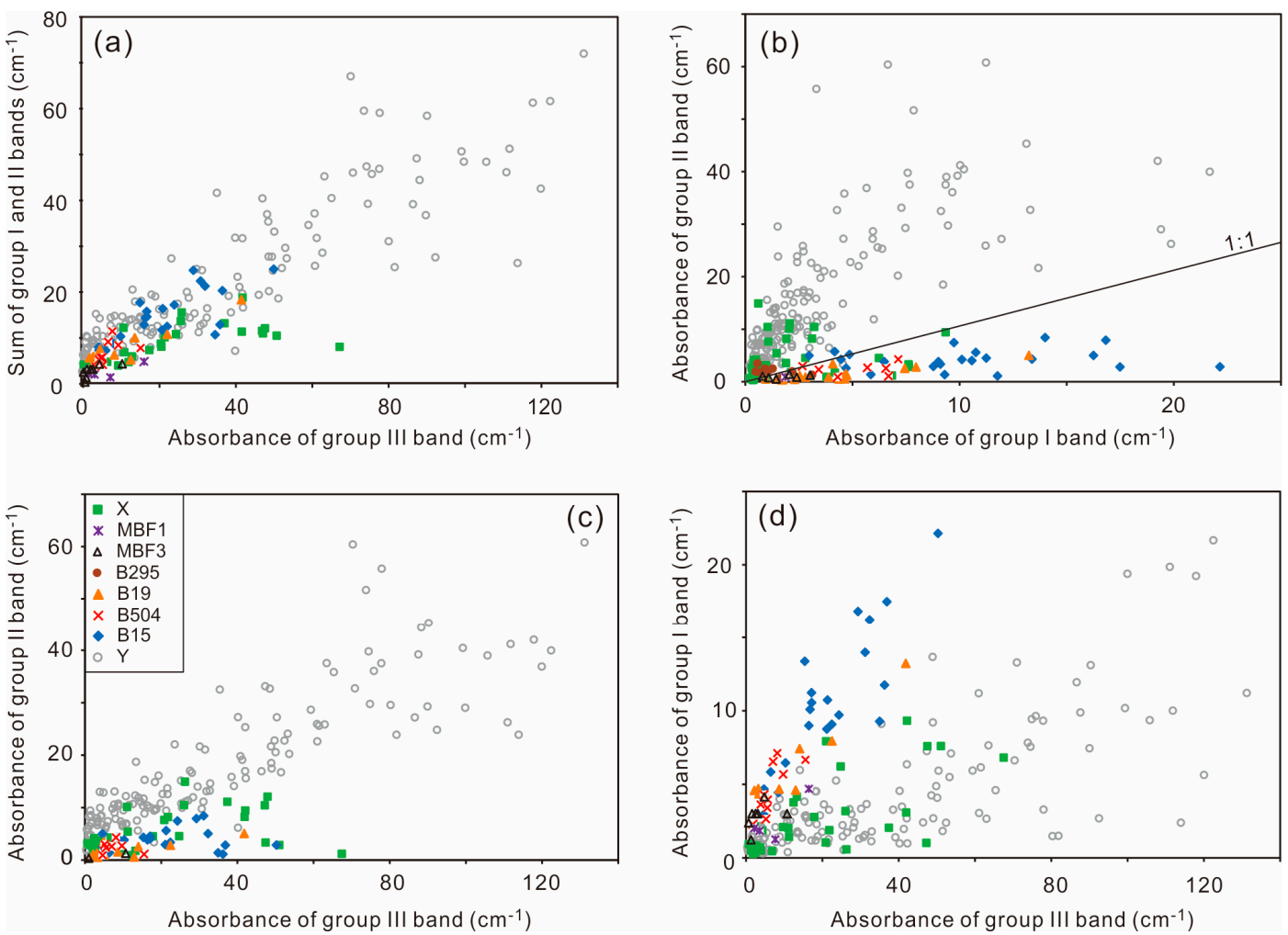

Figure 5. Comparison of the integral absorbance of broad bands in garnet from the Sulu and Sumdo eclogites. (a) The sum of integral absorbance of the group I band at $3627-3686 \mathrm{~cm}^{-1}$ and the group II band at $3565-3603 \mathrm{~cm}^{-1}$ vs. the integral absorbance of the group III band at $3410-3486 \mathrm{~cm}^{-1}$; (b) the group II vs. the group I band; (c) the group II band vs. the group III band; and (d) the group I band vs. the group III band.

\subsection{TEM Observations}

To examine the origin of the group III band, we cut several foils from optically clean domains in garnet grains from fresh UHP eclogite sample $X$ and retrograded HP eclogite sample $Y$. Five foils from water-poor domains are associated with or without the group III band, while four foils from water-rich domains always show the group III band. TEM observations reveal that the former is well crystallized and without defects or small inclusions. In contrast, the later often contains some inclusions.

In the TEM foil from eclogite sample X, EDX spectra indicate that anthophyllite and clinochlore appear as nanometer-sized inclusions in garnet, and thin anthophyllite lamellae (100-200 nm thick) occur between clinochlore and garnet (Figure 6). The mineral phases were identified by the indexed diffraction pattern (FFT) from lattice fringe images. Because enstatite and anthophyllite share similar $a$ 
and $c$ lattice parameters in the unit-cell parameters and both minerals are orthorhombic, we checked four diffraction patterns from different areas in the same grain. Energy-filtered TEM bright-field images show obvious amphibole characteristics (Figure 7a,b), and the observed average parameters are relatively more compatible with anthophyllite (Table 3). The major-element composition ( $\mathrm{MgO}=\sim 31.62 \mathrm{wt} . \%$, $\left.\mathrm{Al}_{2} \mathrm{O}_{3}=\sim 9.66 \mathrm{wt} . \%, \mathrm{SiO}_{2}=\sim 57.01 \mathrm{wt} . \%, \mathrm{FeO}=\sim 0.43 \mathrm{wt} . \%\right)$ from the $\mathrm{EDX}$ analysis also supports that the phase is anthophyllite due to high $\mathrm{Al}_{2} \mathrm{O}_{3}$ content.

In fresh eclogite sample $X$, anthophyllite exsolution lamellae have been partly replaced by clinochlore, as evidenced by the curved grain boundaries between anthophyllite and clinochlore inclusions (Figure 7a). In contrast to the straight grain boundaries between anthophyllite and garnet (Figure 7a,b), the step-like or curved grain boundaries between clinochlore and garnet suggest replacement of garnet by clinochlore (Figures 7c and 8). However, anthophyllite inclusions are absent in garnet from retrograded eclogite sample $Y$, where only clinochlore inclusion lamellae were observed in garnet (Figure 8). In addition, nanometer-sized pores are observed in clinochlore from sample $X$ (Figure 7d), implying the existence of clusters of molecular water.

The high-resolution lattice fringe images of the inclusions in garnet (Figure 7a) reveal lattice coupling between garnet and anthophyllite exsolution lamella (Figure 7e), and between anthophyllite and clinochlore (Figure 7f). In dexed diffraction patterns show that the (110) plane of garnet, the (020) plane of anthophyllite and the (001) plane of clinochlore are parallel to each other (Figure 7g-i). Using EELS spectroscopy, we examined the water distribution in garnet and the relic anthophyllite exsolution lamella in Figure 7a. The $\mathrm{OH}$ peak at approximately $528 \mathrm{eV}$ and prior to the onset of the O-K edge at $532 \mathrm{eV}$ is due to the $\mathrm{OH}$ content $[49,50]$. This $\mathrm{OH}$ peak was absent in the host garnet (Figure 9a) and only observed in the anthophyllite exsolution lamella (Figure 9b). This demonstrates contrasting water distribution across the boundary: water-poor garnet and hydrous anthophyllite.
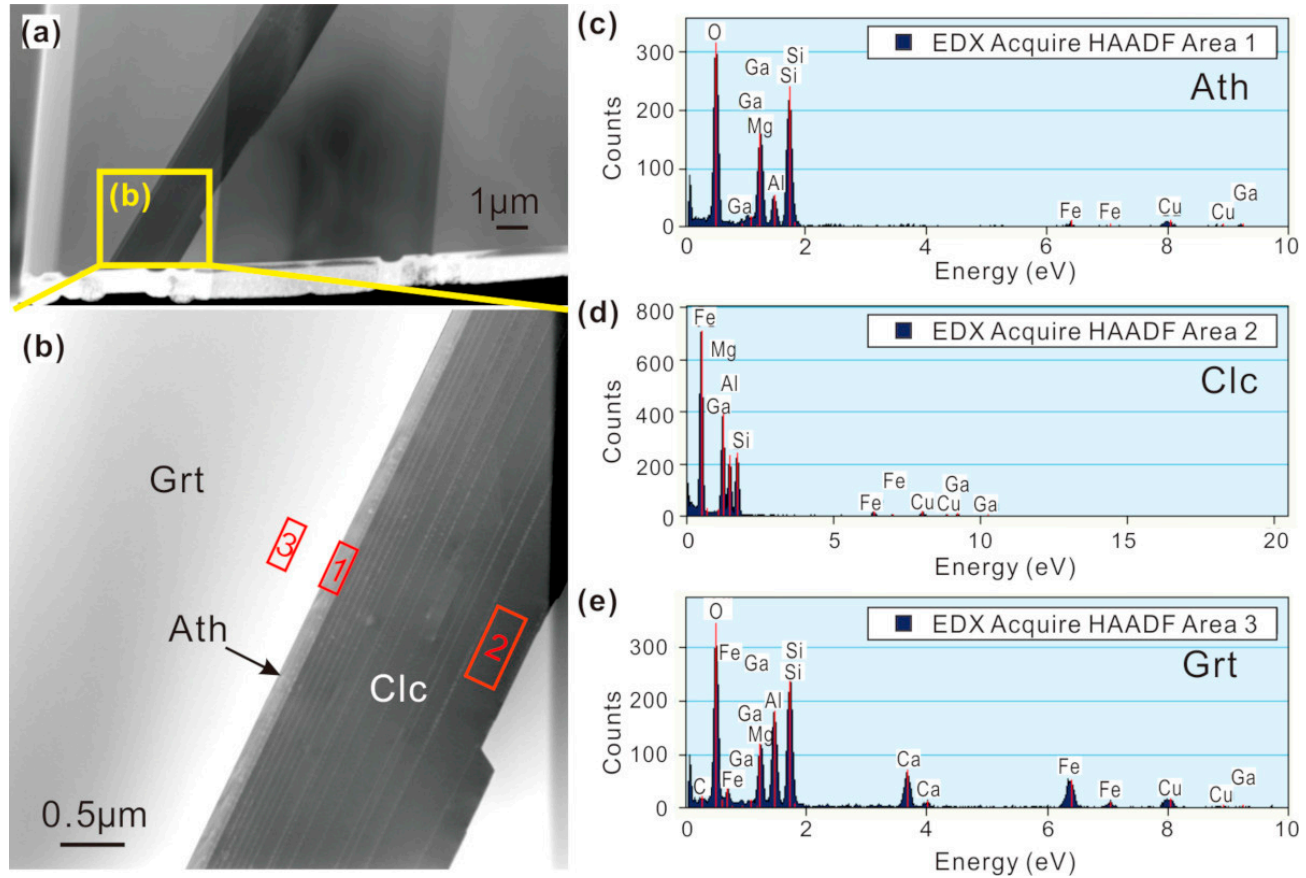

Figure 6. (a,b) Transmission electron microscopy (TEM) images of anthophyllite exsolution lamellae replaced by clinochlore in host garnet from fresh ultrahigh-pressure (UHP) eclogite sample $\mathrm{X}$. The red squares 1, 2 and 3 in (b) indicate the energy-dispersive X-ray (EDX) acquire HAADF areas for phase identification: (c) anthophyllite (Ath), (d) clinochlore (Clc) and (e) garnet (Grt), respectively. 

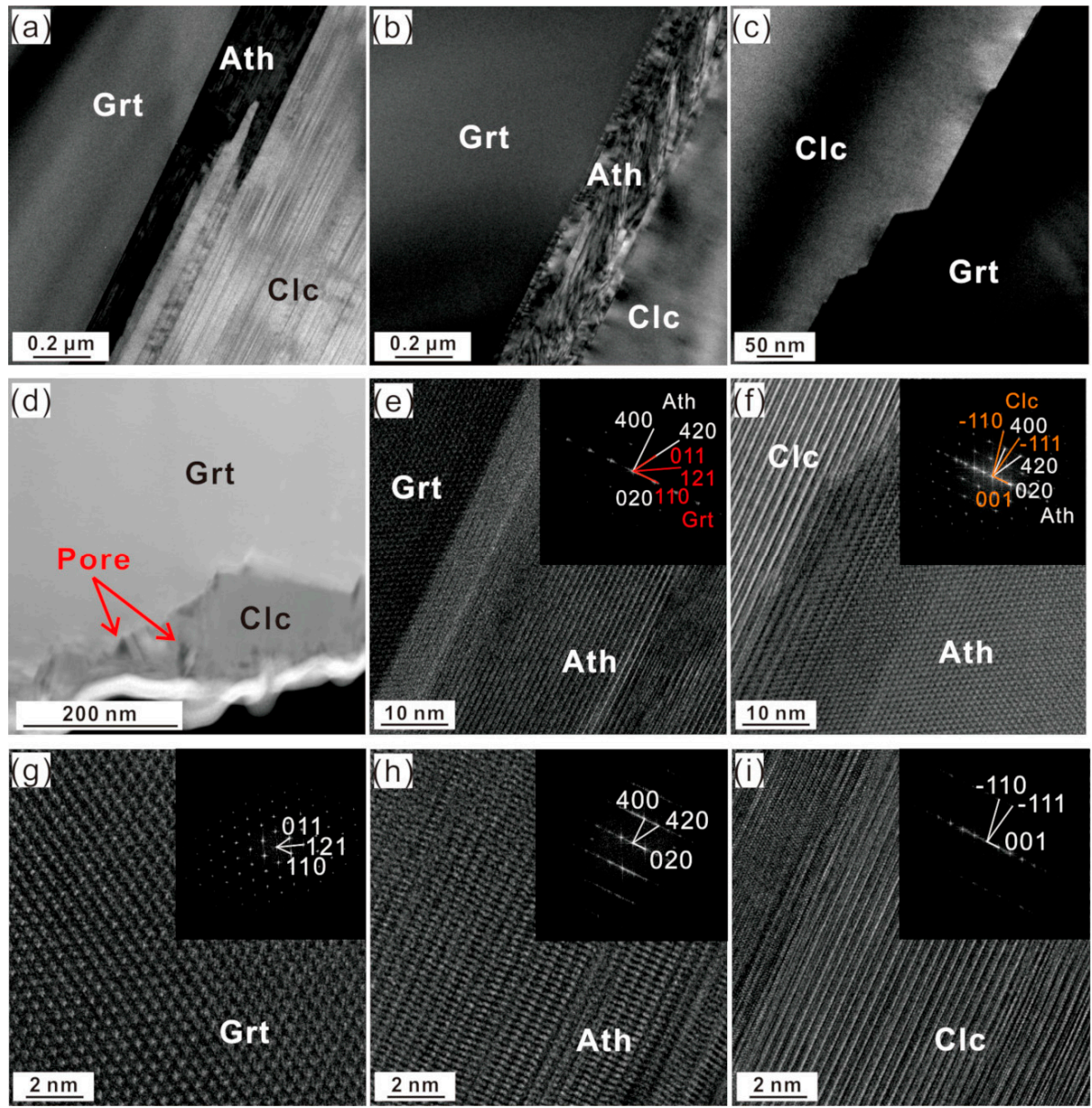

Figure 7. TEM images for fresh UHP eclogite sample X. Energy-filtered bright-field images of $(\mathbf{a}, \mathbf{b})$ garnet with anthophyllite exsolution lamella partly replaced by clinochlore and (c) step-like grain boundary between clinochlore and garnet. (d) High-angle annular dark-field image of nanometer-sized pores within clinochlore. High-resolution lattice fringe images (HREM) with indexed diffraction patterns (fast Fourier transform FFT) for (e) the interface between garnet and anthophyllite, (f) the interface between anthophyllite and clinochlore, (g) garnet, (h) anthophyllite and (i) clinochlore. The numbers in (e-i) are Miller indices (hkl) of lattice planes. Clc, clinochlore; Grt, garnet; Ath, anthophyllite.

Table 3. D-spacing $d_{\mathrm{hkl}}$ and angles between adjacent planes for anthophyllite and enstatite.

\begin{tabular}{cccccc}
\hline \multirow{2}{*}{$\begin{array}{c}\text { Observed Average } \\
\text { Parameters }\end{array}$} & \multicolumn{4}{c}{ Calculated } \\
\cline { 3 - 6 } & & \multicolumn{3}{c}{ Anthophyllite } & \multicolumn{2}{c}{ Enstatite } \\
\hline$d(\mathbf{h k l})(\AA)$ & $\sigma(\AA)$ & $d(\mathbf{h k l})(\AA)$ & $\mathbf{h k l}$ & $d(\mathbf{h k l})(\AA)$ & $\mathbf{h k l}$ \\
\hline 9.23 & 0.192 & 9.01 & $(020)$ & 9.12 & $(200)$ \\
4.14 & 0.084 & 4.12 & $(420)$ & 3.97 & $(220)$ \\
4.76 & 0.033 & 4.63 & $(400)$ & 4.41 & $(221)$ \\
\hline Angle degree $\left(^{\circ}\right)$ & $\sigma\left(^{\circ}\right)$ & Angle degree $\left(^{\circ}\right)$ & & Angle degree $\left(^{\circ}\right)$ & \\
\hline$\alpha=63.1$ & 1.071 & 62.8 & $(020) /(420)$ & 64.2 & $(200) /(220)$ \\
$\beta=26.5$ & 0.479 & 27.2 & $(420) /(400)$ & 25.8 & $(220) /(221)$ \\
\hline
\end{tabular}

Note: The observed average parameters are from four different diffraction patterns of the same garnet grain in sample $X, \sigma$ is the standard deviation. hkl, Miller indices of a lattice plane. 

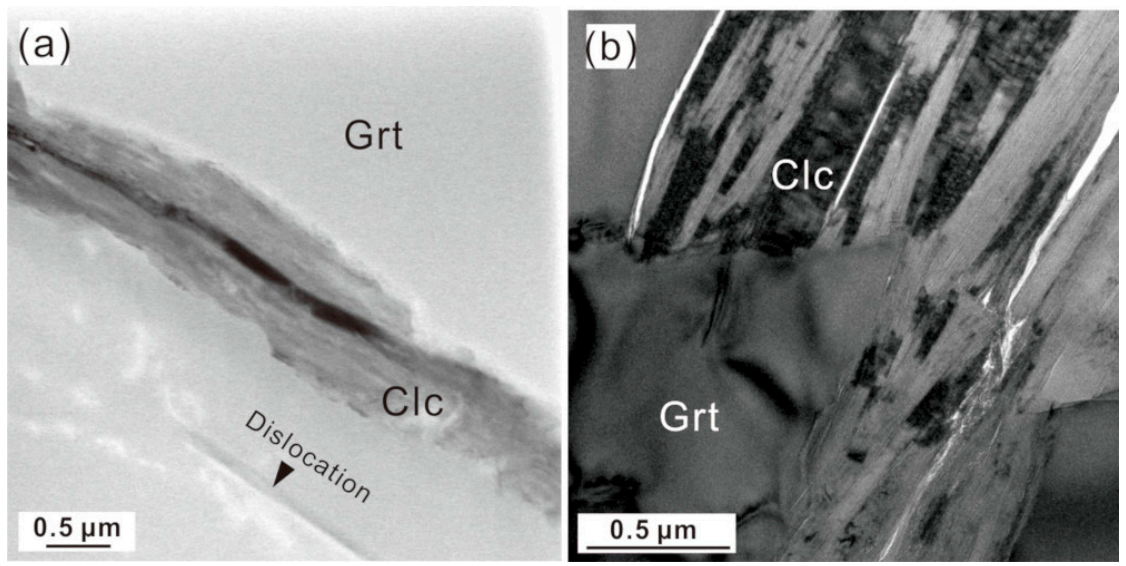

Figure 8. Energy-filtered TEM bright-field images for (a) clinochlore lamellae in host garnet, and (b) the interface between clinochlore and garnet from retrograded HP eclogite sample Y.
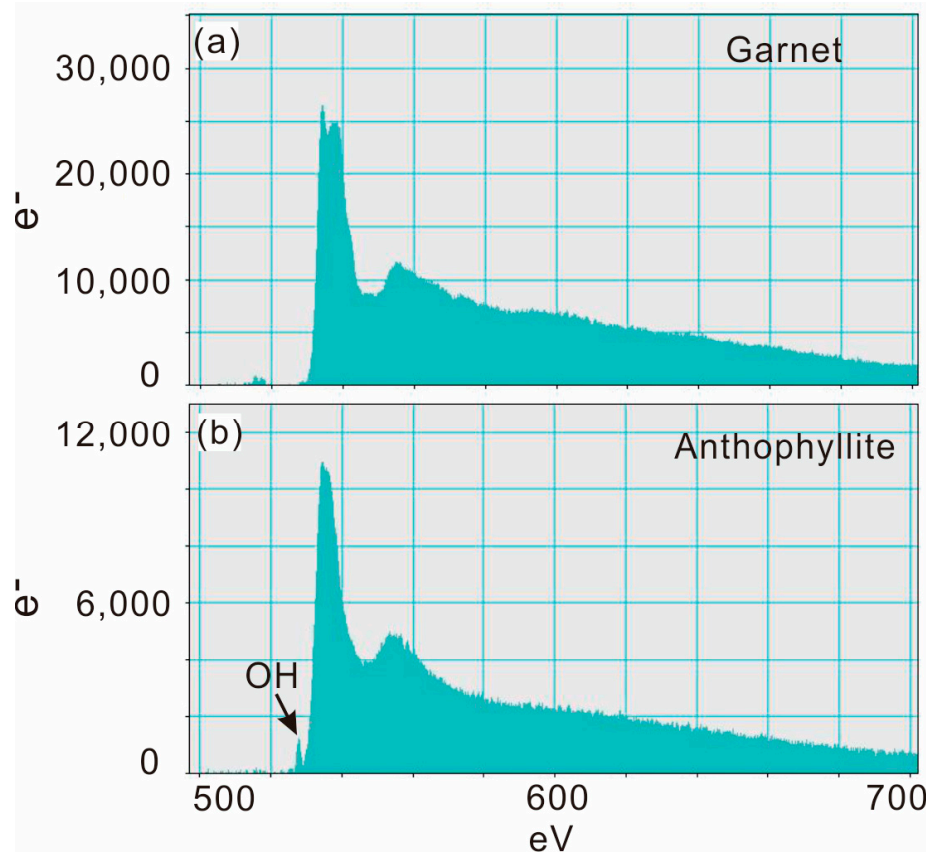

Figure 9. Electron energy-loss spectroscopy (EELs) spectra of (a) host garnet and (b) the relic of anthophyllite exsolution lamella in Figure 7a, showing water-poor garnet and hydrous anthophyllite from sample $X$.

\section{Discussion}

\subsection{Influence of Major Elements on Water Content in Garnet}

Numerous experiments have been carried out to study hydroxyl concentration and storage mechanisms in garnet. Cohen-Addad et al. [51] proposed that water can be incorporated in hydrogarnet by $\mathrm{SiO}_{4}{ }^{4-} \rightarrow(\mathrm{OH})_{4}{ }^{4-}$ substitution, which was confirmed by the experiments on katoite, a chemical end member of garnet, with a full substitution of $\mathrm{SiO}_{4}{ }^{4-} \rightarrow(\mathrm{OH})_{4}{ }^{4-}[52,53]$. However, based on analysis of IR spectra, hydroxyl may have multiple ways to enter the lattice of garnet [54,55]. For instance, Khomenko et al. [56] found titanium substitution in hydrothermally grown pyrope crystals by $\mathrm{Al}^{3+}$ $+\mathrm{Si}^{4+}+4 \mathrm{O}^{2-}=\mathrm{Ti}^{4+}+\square+\left[(\mathrm{OH})_{3} \mathrm{O}\right]^{5-}$. Crystal chemistry revealed that $\mathrm{Ti}^{4+}$ can be substituted into tetrahedral and octahedral vacancies of garnet [57]. This Ti-related hydrogen incorporation mechanism in garnet is supported by a positive correlation between hydroxyl concentration and $\mathrm{TiO}_{2}$ content in garnet from peridotite xenoliths in southern Africa [20] and from massif eclogites in Erzgebirge and 
Fichtelgebirge (Germany) [15]. On the other hand, the iron substitution in garnet by $2\left\{\mathrm{Fe}^{3+}, \mathrm{O}\right\}+\mathrm{H}_{2}$ $\rightarrow 2\left\{\mathrm{Fe}^{2+}, \mathrm{OH}\right\}$ is still controversial. Mookherjee and Karato [28] found that at pressure of 5-9 GPa and temperature of $1100-1200{ }^{\circ} \mathrm{C}$, pyrope-rich garnet can have substantial hydroxyl solubility up to $1000 \mathrm{ppm} \mathrm{H}_{2} \mathrm{O}$. The y proposed a positive correlation between hydroxyl concentration and $\mathrm{Mg \#}$ $(\mathrm{Mg} \#=\mathrm{Mg} /(\mathrm{Mg}+\mathrm{Fe}) \times 100)$ in garnet. However, there is a negative correlation between hydroxyl concentration and $\mathrm{Mg} \#$ in garnet megacrysts crystallized in a kimberlite-like magma at $\sim 5 \mathrm{GPa}$ and $\sim 1100-1400{ }^{\circ} \mathrm{C}[20]$.

Compared with previous studies $[15,20]$, the correlations between hydroxyl concentration and $\mathrm{TiO}_{2}$ content or $\mathrm{Mg} \#$ are absent for our samples (Figure 10a,b). If we only take into account of garnet from fresh and slightly retrograded UHP eclogite samples, the amount of primary structural water correlates with $\mathrm{TiO}_{2}$ content positively (Figure 10a). This result confirms the Ti-related hydrogen substitution mechanism in natural garnet. In addition, our garnet samples from fresh and slightly retrograded UHP eclogites yield a pronounced negative correlation between hydroxyl concentration and $\mathrm{CaO}$ content (Figure 10c), which is consistent with study on garnet pyroxenites in the Sulu UHP terrane [58] but in contrary to observations for eclogitic garnet from the Erzgebirge and Fichtelgebirge complexes [15].
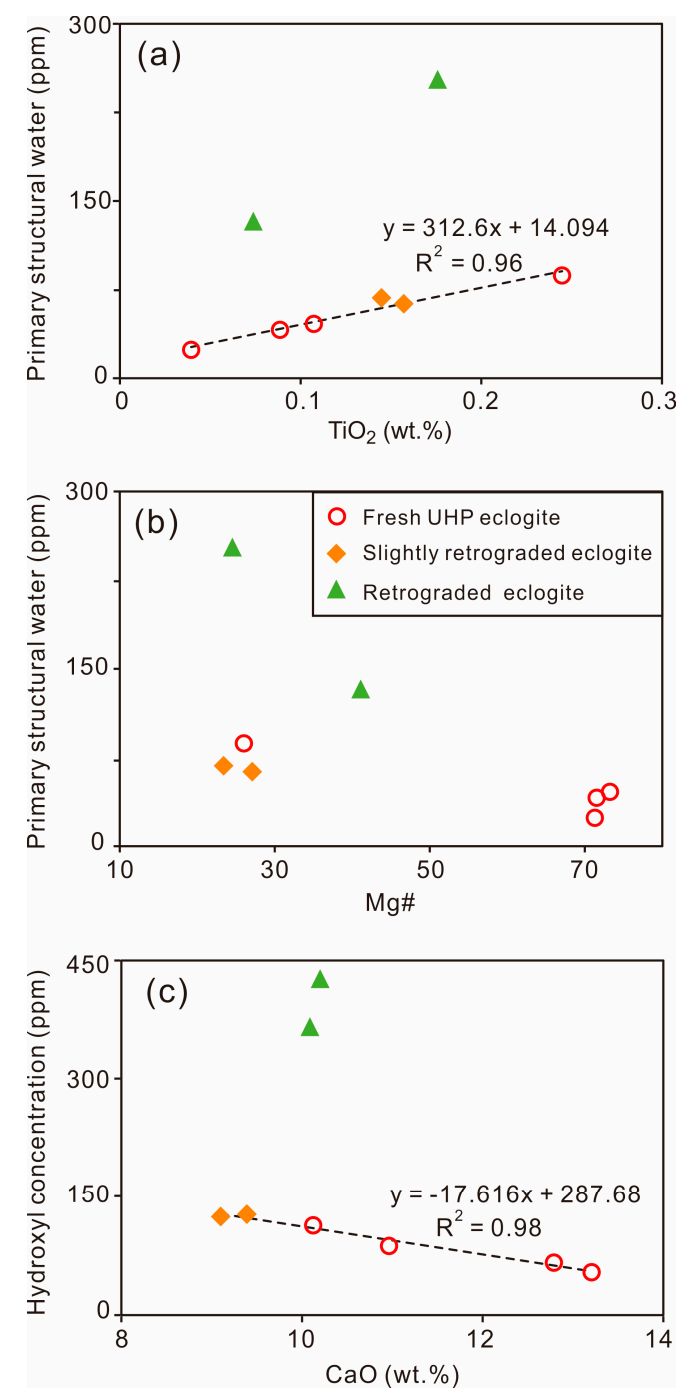

Figure 10. Mean primary structural water content versus (a) $\mathrm{TiO}_{2}$ content and (b) $\mathrm{Mg \#}$ in garnet, and (c) mean hydroxyl concentration versus $\mathrm{CaO}$ content in garnet from the Sulu and Sumdo eclogite samples. The dashed line is the least squares fit to the data of fresh UHP eclogites and slightly retrograded eclogites. 
To check this discrepancy, we compared our data with previous studies on garnet from different localities $[8,10,12,13,15,59]$ (Figure 11). Hydroxyl concentration in garnet from eclogites and garnet pyroxenites shows remarkable variations, especially for samples from the Dabie-Sulu orogen (Figure 11a). However, the correlation between hydroxyl concertation and $\mathrm{CaO}$ content in garnet is very weak, no matter for all samples (Figure 11a) or for eclogitic garnet with hydroxyl concentration less than $300 \mathrm{ppm} \mathrm{H}_{2} \mathrm{O}$ (Figure 11b). For garnet pyroxenites, garnet is relatively Ca-rich and shows lower hydroxyl concentration with increasing $\mathrm{CaO}$ content. Garnet from retrograded eclogite samples B15 and $\mathrm{Y}$ does not follow any above correlations between hydroxyl concentration and major element content, implying that retrograde metamorphism has erased the original influence of mineral chemistry on hydroxyl concentration in garnet.

Liu et al. [13] divided garnet grains from ten UHP eclogites in the Dabie Mountains into two classes according to their hydroxyl concentration. The $y$ found that when hydroxyl concentration in garnet is higher than $400 \mathrm{ppm} \mathrm{H}_{2} \mathrm{O}$, hydroxyl concentration in garnet shows a positive correlation with the $\mathrm{Ca}$ atoms per 12 anions, and a negative correlation with the $\mathrm{Si}, \mathrm{Mg}$, and $\mathrm{Fe}^{2+}$ atoms per 12 anions. However, such relationship is absent for garnet with $\leq 400 \mathrm{ppm} \mathrm{H}_{2} \mathrm{O}$. In this study, both Mg-rich and Fe-rich garnet from the Sulu and Sumdo eclogites can contain high hydroxyl concentration. Unfortunately, the proposed correlation between chemical composition and hydroxyl concentration in water-rich garnet is not observed in our samples (Figure S2).
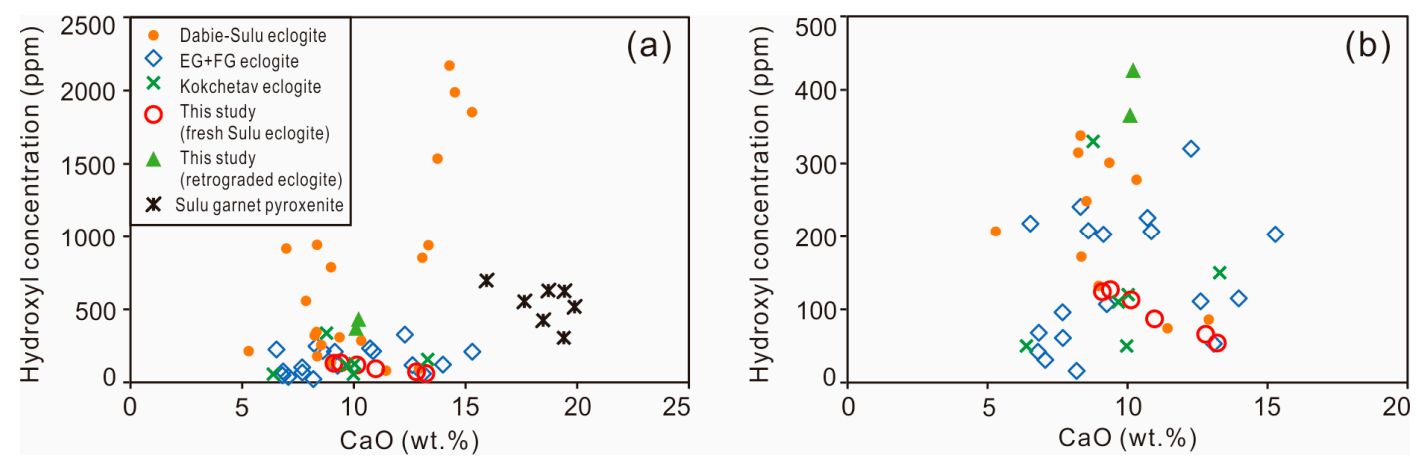

Figure 11. Mean hydroxyl concentration versus $\mathrm{CaO}$ content for garnet from (a) eclogites and garnet pyroxenites, and (b) eclogite samples with mean hydroxyl concentration $<500$ ppm $\mathrm{H}_{2} \mathrm{O}$. Garnet samples are from massif eclogites in the Dabie-Sulu orogen [10,11,13,59], the Kokchetav massif [8] and the Erzgebirge and Fichtelgebirge (EG + FG) complexes [15], and from garnet pyroxenites in the Sulu UHP terrane [58].

In addition, Bell and Rossman [20] noticed that the peak position of the strongest band near $3570 \mathrm{~cm}^{-1}$ (the group II band) shifts to lower wavenumber from 3580 to $3565 \mathrm{~cm}^{-1}$ with decreasing $\mathrm{Mg} \#$ in garnet megacrysts. In our samples, only UHP eclogite sample $X$ and retrograded HP eclogite sample $\mathrm{Y}$ show the predominance of the group II band over the group I band (Figure 5b). However, for Mg-rich garnet from sample X, there is no any correlation between the peak position of the group II band and Mg\# (Figure 12a,b). This trend is only observed for garnet grains without the group III group from sample Y (Figure 12d). Further experiments are needed to explore the influence of Fe-related hydrogen substitution in garnet.

It is noteworthy that the narrow bands $\mathrm{A}$ to $\mathrm{K}$ have fixed wavenumbers despite of different hydroxyl concentration in garnet (Figure 3). To investigate the origin of these narrow bands, we define the strength coefficient of a narrow band $(\eta)$ as the ratio between the integrated area of a narrow band $\left(\Delta_{\mathrm{n}}\right)$ and the integrated area of total characteristic bands of hydroxyl $\left(\Delta_{\mathrm{h}}\right)$ :

$$
\eta=\Delta_{\mathrm{n}} / \Delta_{\mathrm{h}}
$$


For garnet from $\mathrm{Mg}$-rich eclogite sample $\mathrm{X}$, the strength coefficients of narrow bands $\mathrm{C}$ and $\mathrm{K}$ decrease with $\mathrm{Fe}^{2+}$ concentration (Figure 13a,b), whereas that of the narrow band I decreases with $\mathrm{Cr}$ concentration (Figure 13c). However, such relationships are ambiguous in garnet from retrograded eclogite sample $\mathrm{Y}$, implying different substitution mechanisms due to the compositional change. For other narrow bands, we did not find any correlation between the strength coefficients and garnet compositions, probably because of the limited data. The infrared absorption peak of anthophyllite is near $3675 \mathrm{~cm}^{-1}$ [60] (Figure 14a), which agrees with the narrow peak J at 3670-3678 $\mathrm{cm}^{-1}$. Given the stability of wavenumbers of the narrow bands with varying hydroxyl concentration, these narrow bands could be used as "fingerprint peaks" to trace the influence of different cations on hydroxyl substitution in garnet.
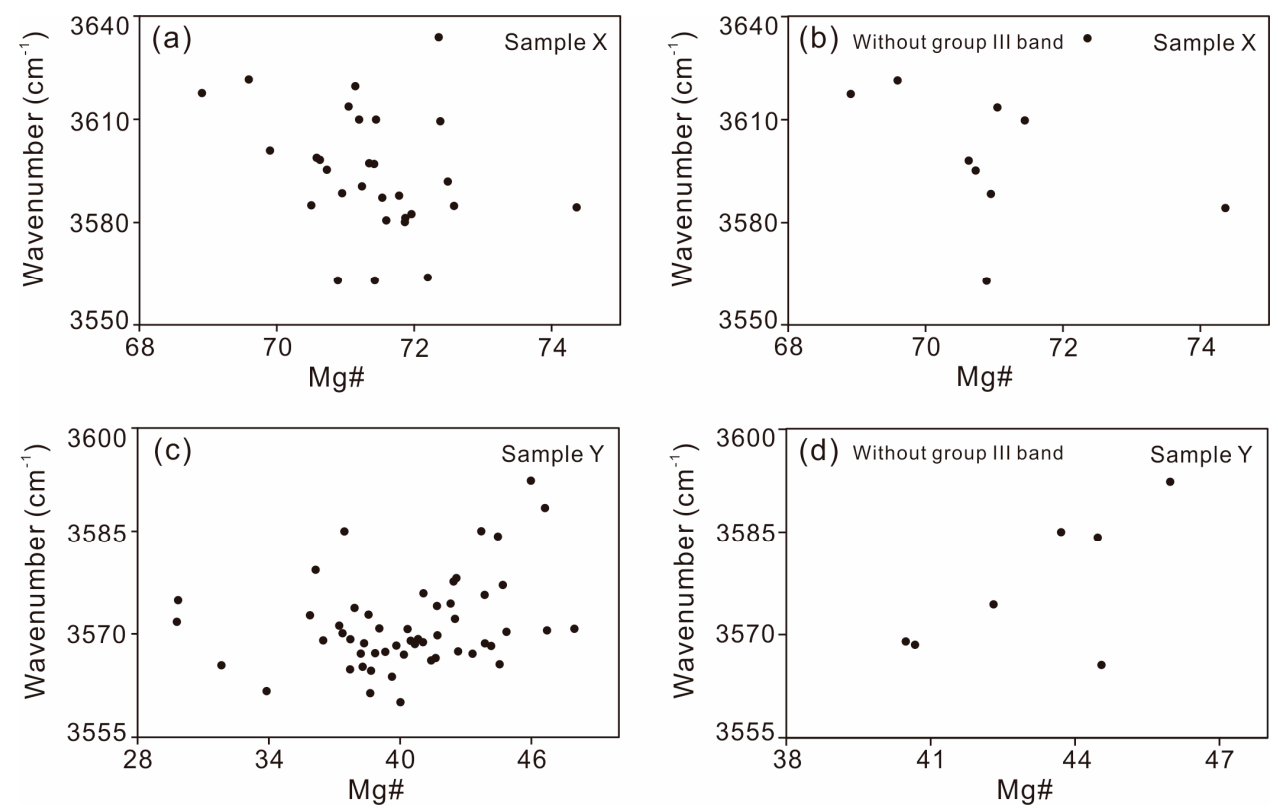

Figure 12. The peak position of the group II band vs. Mg\# in garnet from UHP eclogite sample X and retrograded HP eclogite sample Y. (a,c) for all grains, $(\mathbf{b}, \mathbf{d})$ for grains without the group III band.
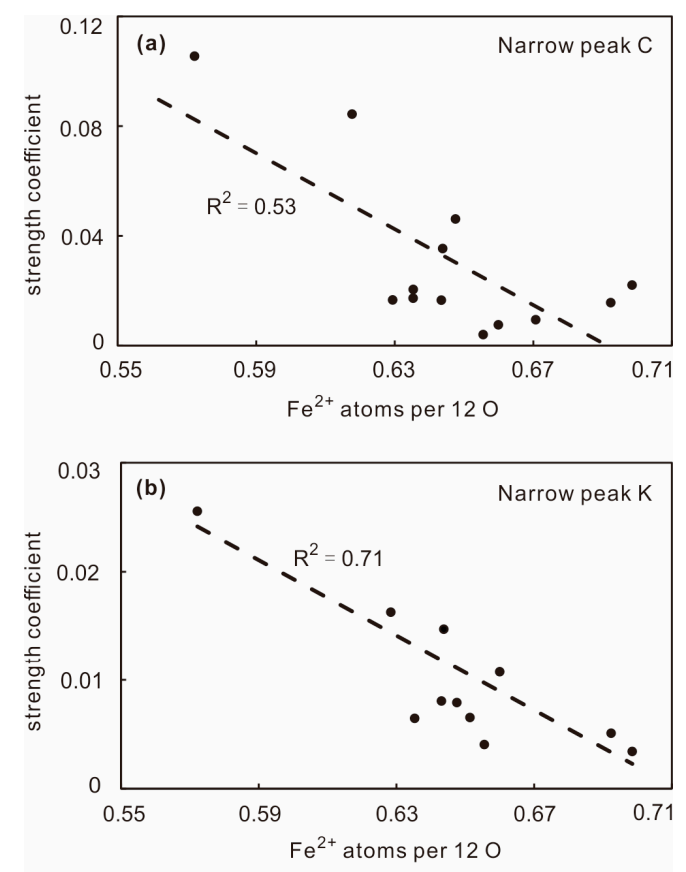

Figure 13. Cont. 


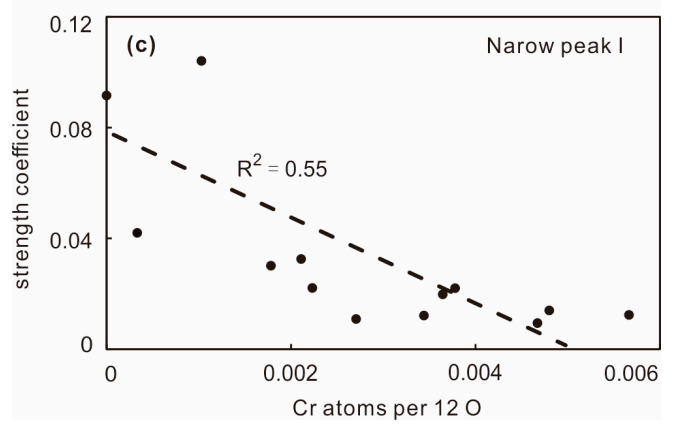

Figure 13. Relationships between the strength coefficient of narrow bands and major element compositions for fresh eclogite sample $\mathrm{X}$. (a) The strength coefficient of narrow band $\mathrm{C}$ vs. $\mathrm{Fe}^{2+}$ atoms per 12 anions, (b) the strength coefficient of narrow band $\mathrm{K}$ vs. $\mathrm{Fe}^{2+}$ atoms per 12 anions, and (c) the strength coefficient of narrow band I vs. Cr atoms per 12 anions.

\subsection{Origin of the Broad Band Near $3400 \mathrm{~cm}^{-1}$}

A broad band near $3400 \mathrm{~cm}^{-1}$ (group III band) in IR spectra of synthetic pyrope [61] and garnet crystals from diamondiferous UHP rocks [9] has been attributed to the vibration of $\left(\mathrm{H}_{2} \mathrm{O}\right)_{n}$ clusters in fluid inclusions for a long time. Associated with the broad IR band near $3440 \mathrm{~cm}^{-1}$, clusters of water molecules were found as heterogeneously distributed inclusions in eclogitic garnet with the size to $0.063 \mu \mathrm{m}$ in bright-field TEM images [5]. Since then, the widespread group III band in IR spectra of eclogitic garnet was interpreted as molecular water in fluid inclusions [9-15]. As shown in Figure 5, although the broad group III band was excluded in calculation of hydroxyl concentration, it has strong influence on hydroxyl absorption bands in garnet. Hence its origin, either intrinsic or secondary, is critical for tracing fluid activity of UHP rocks in subduction channels.

In this study, water-poor domains in garnet are well crystallized, free of inclusions, and with or without the group III band. In contrast, water-rich domains in garnet always show the group III band, and often contain nanometer-sized anthophyllite exsolution lamellae and clinochlore inclusions (Figure 7). Anthophyllite exsolution lamellae locally appear in garnet from UHP eclogite sample X and have been partly replaced by clinochlore, whereas clinochlore lamellae widely occurs in garnet from both UHP eclogite sample $\mathrm{X}$ and retrograded HP eclogite sample $\mathrm{Y}$. The $\mathrm{OH}$ stretching absorption bands of clinochlore and chlorite include a broad band at $3407-3453 \mathrm{~cm}^{-1}$ with the FWHM $>160 \mathrm{~cm}^{-1}$, and a band at 3565-3610 $\mathrm{cm}^{-1}$ with the FWHM $<100 \mathrm{~cm}^{-1}$ [33,62-64] (Figure 14a). This means when garnet contains nanometer-sized inclusions of chlorite minerals, the overlapping absorption bands of garnet and chlorite will make them indistinguishable in IR spectra (Figure 14b). The refore, even using the Gaussian fit to exclude the group III band, the remaining contribution of chlorite minerals to the group II band at 3565-3603 $\mathrm{cm}^{-1}$ cannot be ruled out. This explains why the absorbance of the group III band shows a positive correlation with the sum of absorbance of group I and II bands (Figure 5a) and with the absorbance of group band II for garnet (Figure $5 \mathrm{c}$ ), as observed for eclogitic garnets from the Dabie Mountains [12] and the Erzgebirge and Fichtelgebirge complexes [14,15].

We did not directly observe the clusters of molecular water in TEM observations as Su et al. [5]. However, in water-rich domains in garnet, we found nanometer-sized pores in clinochlore inclusions (Figure 7d), which can provide the space for clusters of molecular water. It is worthy to note that clinochlore inclusions are absent in some foils from water-rich domains, where the group III band still occurs. This can be explained by the sole contribution of molecular water in fluid inclusions to the group III band and hydroxyl enrichment by hydrogen diffusion, or heterogenous distribution of fluid inclusions and/or clinochlore inclusions in garnet because of the much smaller observation area in TEM than in FTIR analysis. 

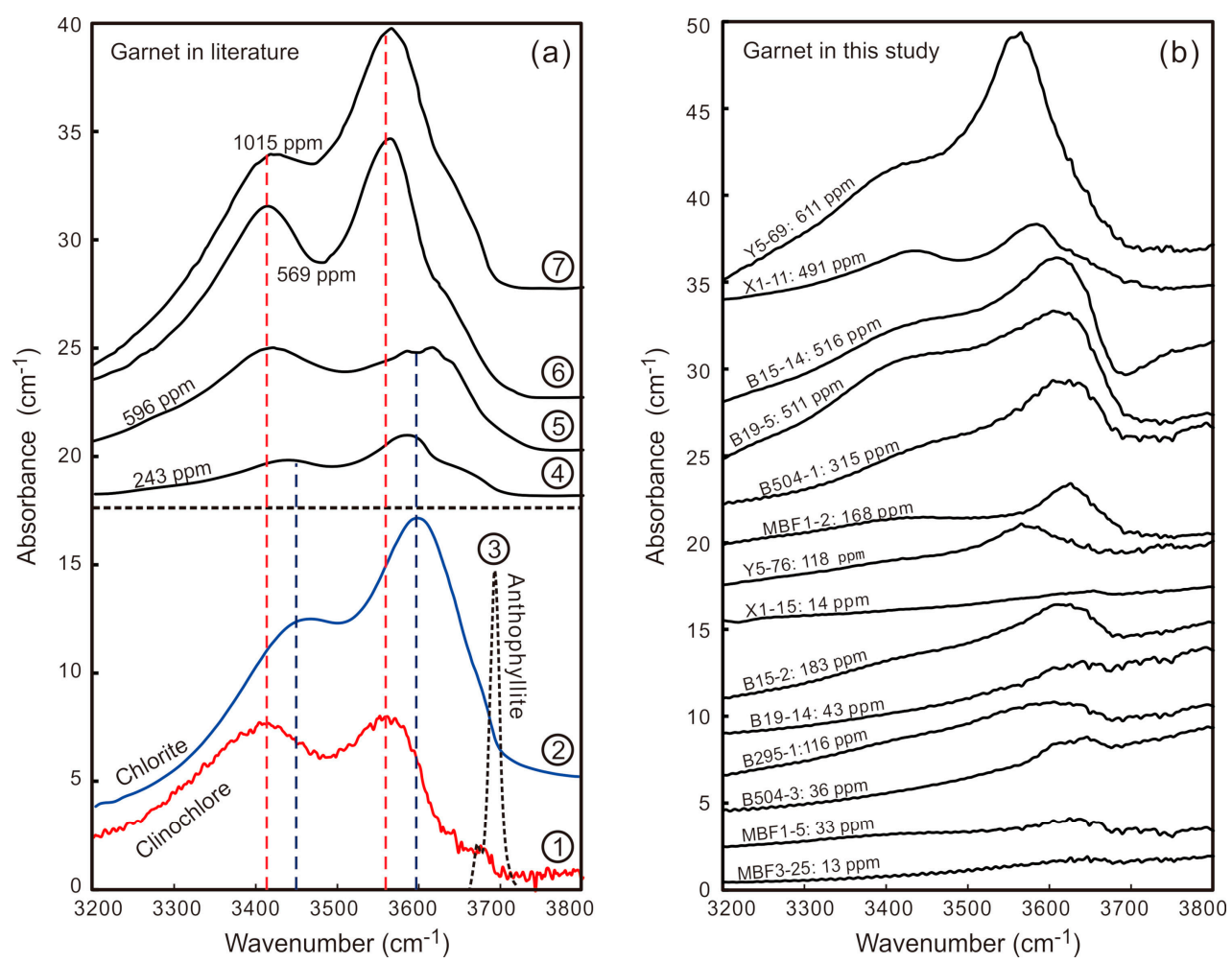

Figure 14. (a) IR spectra of water-rich garnet, chlorite, clinochlore, and anthophyllite from previous studies. References are numbered as: 1:[62]; 2:[33]; 3:[60]; 4:[59]; 5:[59]; 6:[12]; 7:[15]. (b) Representative unpolarized IR spectra of garnet in this study. All the IR spectra were normalized to $1 \mathrm{~cm}$ thickness and offset vertically for comparison. After excluding the broad group III band at 3410-3486 cm ${ }^{-1}$, hydroxyl concentration in garnet is given next to the correspondent IR spectrum.

A combination of thermal conversion element analyzer (TC/EA) with isotope ratio mass spectrometry (MS) allows determination of both hydrogen isotopes and the total water content of garnet [65]. During TC/EA-MS analyses on garnet, preheating at $350^{\circ} \mathrm{C}$ for $4 \mathrm{~h}$ removed the most intensity of the group III band without loss of structural $\mathrm{OH}$, then preheating at $600^{\circ} \mathrm{C}$ for $6 \mathrm{~h}$ totally removed the group III band but also caused partial loss of structural $\mathrm{OH}$ [65]. This suggests that molecular $\mathrm{H}_{2} \mathrm{O}$ has a much faster diffusion rate than structural $\mathrm{OH}$ in garnet, as observed in water diffusion experiments in silicate glasses [66-68]. Gong et al. [65] attributed the change of the group III band to the loss of molecular $\mathrm{H}_{2} \mathrm{O}$ during the stepwise heating process, but did not explain why the final loss of molecular $\mathrm{H}_{2} \mathrm{O}$ in garnet occurred until $600{ }^{\circ} \mathrm{C}$ and was accompanied with partial loss of structural $\mathrm{OH}$. The breakdown temperature of chlorite minerals is a function of composition, pressure, and oxygen fugacity. For intermediate magnesium-iron chlorites of the clinochlore-daphnite series, the breakdown temperature of chlorites decreases with decreasing pressure and smaller Mg\# [69]. Extrapolating experiments of Mconie et al. [69], the upper stability limit of clinochlore is $\sim 600{ }^{\circ} \mathrm{C}$ at room pressure and Ni-NiO buffer. The refore, the two-step loss of the group III band in the TC/EA-MS analyses of garnet $[6,11,12,65]$ can be better explained by the loss of molecular $\mathrm{H}_{2} \mathrm{O}$ in micro-inclusions at $350^{\circ} \mathrm{C}$, and the dehydration reaction of clinochlore inclusions at $600{ }^{\circ} \mathrm{C}$.

Gong et al. (2007) [65] found $\delta \mathrm{D}$ values of $-86 \%$ o for structural $\mathrm{OH}$ and $-101 \%$ o for molecular $\mathrm{H}_{2} \mathrm{O}$ in a garnet crystal from the Dabie UHP eclogite. The negative correlations between the total water content and $\delta \mathrm{D}$ values for garnet, omphacite, and rutile in eclogites from the CCSD borehole demonstrate a preferential loss of the D-poor molecular water from the NAMs by diffusion relative to the structural $\mathrm{OH}$ during exhumation [11,70]. Meanwhile, amphibole and plagioclase in amphibolites have $\delta \mathrm{D}$ values similar to, or greater than garnet and omphacite from the adjacent eclogites, and epidote and muscovite have higher $\delta \mathrm{D}$ values than amphibole. The refore, there are two origins of 
retrograde fluid with contrasting hydrogen isotope compositions: D-depleted fluid by exsolution of molecular $\mathrm{H}_{2} \mathrm{O}$ and structural $\mathrm{OH}$ from NAMs, and D-rich fluid by decomposition of hydrous minerals from surrounding rocks during amphibolite-facies retrogression metamorphism. Statistically, the $\delta \mathrm{D}$ values of molecular $\mathrm{H}_{2} \mathrm{O}$ in eclogitic garnet show larger variations than the structural $\mathrm{OH}$, suggesting dual origins of molecular $\mathrm{H}_{2} \mathrm{O}$ in garnet [70].

As shown in Table 2 and Figures 5 and 10, garnet from fresh and slightly retrograded eclogites is characterized by relatively low hydroxyl concentration, weak correlation between the intensity of the group-III band and the group II band, and evident correlations of the amount of primary structural water with $\mathrm{TiO}_{2}$ content. In contrast, garnet from retrograded eclogites shows very high hydroxyl concentration, positive correlation between the intensity of the group-III band and the group II band, and independence of the amount of primary structural water on mineral chemistry. Hence we propose that water related with the group III band in garnet predominantly came from the intrinsic D-depleted fluid in NAMs for fresh and slightly retrograded eclogites, but includes both intrinsic D-depleted fluid in NAMs and secondary D-rich fluid from hydrous minerals for retrograded eclogites.

Micrometer-sized aqueous fluids with variable salinities and gas species $\left(\mathrm{N}_{2^{-}}, \mathrm{CO}_{2^{-}}\right.$, or $\mathrm{CH}_{4}$-rich) have been found as primary inclusions in garnet from the Dabie-Sulu eclogites [71,72]. The great diversity of fluid compositions and large-scale ${ }^{18} \mathrm{O}$ depletion in UHP rocks from the Dabie-Sulu orogen indicate very limited fluid-rock interaction during peak metamorphism and retrograde metamorphism [73]. For UHP eclogites and surrounding gneisses in the Sulu terrane, the $\delta \mathrm{D}$ values for the coexisting hydrous minerals [70] do not follow the D-enrichment sequence derived from experimental studies for equilibrium $\mathrm{H}$ isotope fractionation at $T>500{ }^{\circ} \mathrm{C}$ [74-76], which can be attributed to the disequilibrium $\mathrm{H}$ fractionation in coexisting minerals because of the different rates of $\mathrm{H}$ diffusion. Similar with the oxygen isotope observations, the $\mathrm{H}$ isotope exchange between garnet and omphacite also occurred in a relatively closed system during exhumation of eclogites [70].

\subsection{Origin of Nanometer-Sized Inclusions in Garent}

A striking observation from our experiments is anthophyllite inclusions interlayered between clinochlore and garnet in foils cut from fresh UHP eclogite sample X (Figures 6 and 7). The wellpreserved microstructure of anthophyllite within garnet implies its exsolution origin. Sodic amphibole exsolution lamellae in garnet have been documented in garnet peridotites from the North Qaidam UHP metamorphic belt, and was interpreted as decomposition of sodic and $\mathrm{OH}$-bearing parental majoritic garnet to amphibole, rutile and "normal" garnet during exhumation from a depth large than $200 \mathrm{~km}(P$ $>7 \mathrm{GPa}$ ) [34,77]. Sakamaki et al. [78] found similar sodic amphibole exsolution lamellae in water-poor pyrope from kimberlites in the Colorado Plateau. The y proposed that breakdown of hydrous Na-rich majoritic garnet will produce amphibole lamellae and dehydrate garnet during exhumation to depths shallower than $100 \mathrm{~km}$ by the following reaction:

$$
\begin{gathered}
\left(\mathrm{Mg}, \mathrm{Ca}, \mathrm{Na}_{x}\right)_{3}\left(\mathrm{Al}_{2-x}, \mathrm{Mg}_{x}\right)_{2} \mathrm{Si}_{3} \mathrm{O}_{12-2 x}(\mathrm{OH})_{2 x} \rightarrow \\
x \mathrm{NaCa}_{2}\left(\mathrm{Mg}_{4} \mathrm{Al}\right) \mathrm{Si}_{6} \mathrm{Al}_{2} \mathrm{O}_{22}(\mathrm{OH})_{2}+(1-2 x)(\mathrm{Mg}, \mathrm{Ca}) \mathrm{Al}_{2} \mathrm{Si}_{3} \mathrm{O}_{12}
\end{gathered}
$$

In contrast to the sodic amphibole exsolution lamellae in the size of tens to hundreds microns within "original" majoritic garnet $[34,77,78]$, anthophyllite exsolution lamellae in garnet from sample $X$ are nanometer-sized and invisible in an optical microscope. Hence it is impossible to calculate the majoritic component of garnet. Eclogites from the CCSD boreholes and the Maobei village in the Sulu terrane experienced UHP metamorphism at $770-840{ }^{\circ} \mathrm{C}$ and 3.2-4.0 GPa (>100 km) [79]. Garnet in sample $X$ shows relatively small Si content ( 2.91 for 12 oxygen) (Table 1 ) and low water content next to the hydrous anthophyllite exsolution (Figure 9). The refore, anthophyllite exsolutions may be caused by decomposition of hydrous garnet during exhumation: 
Substitution of $\mathrm{H}^{+}$to $\mathrm{Si}^{4+}$ in the form of $(\mathrm{OH})_{4}{ }^{4-}$ cluster could meet the Si saturation in garnet $[52,53]$. During exhumation process, further fluid activity will result in alteration of anthophyllite to clinochlore by addition of water and $\mathrm{Al}$ content from the host garnet or surrounding hydrous minerals:

$$
\text { anthophyllite }+\mathrm{H}_{2} \mathrm{O}+\mathrm{Al}^{3+} \rightarrow \text { clinochlore }
$$

Different from fluid inclusions that may enhance hydroxyl concentration in nearby domains in garnet by hydrogen diffusion [15], the occurrence of nanometer-sized anthophyllite exsolution lamellae is accompanied by dehydration of nearby domains in garnet (Figure 9), although the IR spectrum yields high hydroxyl concentration in the $40 \times 40 \mu \mathrm{m}^{2}$ analyzed area. Our TEM images also record the partly replacement of anthophyllite by clinochlore in garnet from UHP eclogite sample X (Figure 7a,b). The refore, these nanometer-sized anthophyllite exsolution lamellae and clinochlore inclusions in garnet preserved the evidence of water transportation within the lattice of garnet during exhumation. When fluid influx is sustainable, excess water will be stored as clusters of molecular $\mathrm{H}_{2} \mathrm{O}$ in nanometer-sized pores in clinochlore inclusions (Figure 7d). In contrast, garnet from retrograded HP eclogite sample $\mathrm{Y}$ is lack of anthophyllite exsolution lamellae but often contains clinochlore inclusions, suggesting that clinochlore is the dominant hydrous mineral within garnet at lower pressure. All these solid and fluid inclusions are responsible for the heterogenous water distribution in garnet from a grain scale to a thin section scale.

\subsection{Contribution of Garnet to the Water Cycle}

In order to estimate the contribution of garnet to the deep water cycle, we compared hydroxyl concentration in natural garnet with the calculated hydroxyl solubility in pyrope under different $P-T$ conditions. Lu and Keppler [29] found that hydroxyl solubility $\left(\mathrm{C}_{\mathrm{OH}}\right)$ in pyrope increases with pressure and can be described by the equation up to $10 \mathrm{GPa}$

$$
c_{\mathrm{OH}}=A f_{\mathrm{H}_{2} \mathrm{O}}^{0.5} \exp \left(-\frac{\Delta E+P \Delta V}{R T}\right)
$$

where $f_{\mathrm{H}_{2} \mathrm{O}}$ is the water fugacity, $R$ is the gas constant, $P$ is pressure, $T$ is temperature, $\Delta E$ is the reaction enthalpy, $A$ is $0.679 \mathrm{ppm} / \mathrm{bar}^{0.5}$, and $\Delta V$ is $5.71 \mathrm{~cm}^{3} / \mathrm{mol}$ at $1000{ }^{\circ} \mathrm{C}$. At $1000{ }^{\circ} \mathrm{C}$ and $2 \mathrm{GPa}$, the enthalpy of the hydroxylation reaction $\Delta H$ is $14 \mathrm{~kJ} / \mathrm{mol}$. Using their experimental data, $\Delta E$ is estimated as $2580 \mathrm{~J} / \mathrm{mol}$ and $A$ is $0.866 \mathrm{ppm} / \mathrm{bar}^{0.5}$ for different temperatures. The water fugacity $f_{\mathrm{H}_{2} \mathrm{O}}$ was determined using the analytical solution [80]:

$$
\ln f_{\mathrm{H}_{2} \mathrm{O}}=\left[\frac{\ln \rho+A^{\text {res }}}{R T}+\frac{P}{\rho R T}\right]_{\rho \text { at } P}+\ln (R T)-1
$$

where $A^{\text {res }}$ is residual Helmholtz energy, $\rho$ is molar density $(n / V)$. The molar volume of pure water at different pressure and temperature was estimated by the equation of state [81]:

$$
\begin{gathered}
\frac{A^{\text {res }}}{n R T}=c_{1} \rho+\left[\frac{1}{c_{2}+c_{3} \rho+c_{4} \rho^{2}+c_{5} \rho^{3}+c_{6} \rho^{4}}-\frac{1}{c_{2}}\right]-\left(\frac{c_{7}}{c_{8}}\right)\left[\exp \left(-c_{8} \rho\right)-1\right] \\
-\left(\frac{c_{9}}{c_{10}}\right)\left[\exp \left(-c_{10} \rho\right)-1\right]
\end{gathered}
$$

where $c_{1-10}$ refer to different temperature-related parameters:

$$
c_{i}=c_{i, 1} T^{-4}+c_{i, 2} T^{-2}+c_{i, 3} T^{-1}+c_{i, 4}+c_{i, 5} T+c_{i, 6} T^{2}
$$

The coefficients $c_{i, j}$ in Equation (9) for $\mathrm{H}_{2} \mathrm{O}$ were provided by Pitzer and Sterner [81]. We adopted representative geothermal profiles from different tectonic settings: a P-T path of the Sulu UHP belt [35], the Western Superior Province for a cold and stable Archean craton, the Dabie Mountains for a normal crust after Triassic continental collision, and the North Jiangsu basin for an active extensional basin [82] 
(Figure 15a). The average crustal and mantle densities are $2.85 \mathrm{~g} / \mathrm{cm}^{3}$ and $3.3 \mathrm{~g} / \mathrm{cm}^{3}$, respectively. As shown in Figure 15b, hydroxyl solubility in pyrope increases with depth for all tectonic settings, with the highest value in the North Jiangsu basin because of its highest temperature at depth $<120 \mathrm{~km}$. The cold thermal structure of the Wester Superior Province is comparable with the $P-T$ path of the Sulu UHP rocks during subduction, resulting in the lowest hydroxyl solubility in pyrope. During exhumation of the Sulu UHP rocks, hydroxyl solubility in pyrope will be slightly higher because of the increased temperature. At a depth of $150 \mathrm{~km}$, the hydroxyl solubility in pyrope can reach $180 \mathrm{ppm}$ beneath the Dabie Mountains and the North Jiangsu basin, but only about 150 ppm beneath the Wester Superior Province. However, in experiments of Mookherjee and Karato [28], water solubility in pyrope-rich garnet can reach $1000 \mathrm{ppm}$ at pressure of 5-9 GPa and temperature of $1100-1200{ }^{\circ} \mathrm{C}$, about five times the value from $\mathrm{Lu}$ and Keppler [29].

Hydroxyl concentration in natural garnet from eclogites shows larger variations from nearly dry to 2500 ppm $\mathrm{H}_{2} \mathrm{O}$ ([6,8-10,12-15,59]; this study). To avoid overlapping of data points, we only used the mean hydroxyl concentration of each sample and excluded the samples with hydroxyl concentration $>500$ ppm $\mathrm{H}_{2} \mathrm{O}$ in Figure 15b. All garnet samples with extremely high hydroxyl concentration come from retrograded eclogites with different chemical compositions. It is interesting to notice that some slightly retrograded eclogites such as samples B19 and B504 contain hydroxyl concentration close to the calculated water solubility of pyrope. Our study indicates that compared with synthetic garnet in water solubility experiments, garnet from massif eclogites often contain randomly distributed nanometer-sized inclusions of chlorite minerals and fluid inclusions, which can significantly enhance hydroxyl concertation and water heterogeneity in garnet. By contrast, garnet from kimberlite-brought peridotite xenoliths in cratons [23-26] and garnet megacrysts from kimberlite-like magma (15-74 ppm $\mathrm{H}_{2} \mathrm{O}$ ) [27] contain $<100 \mathrm{ppm} \mathrm{H}_{2} \mathrm{O}$, far below the water solubility of pyrope at depth (Figure $15 \mathrm{~b}$ ).
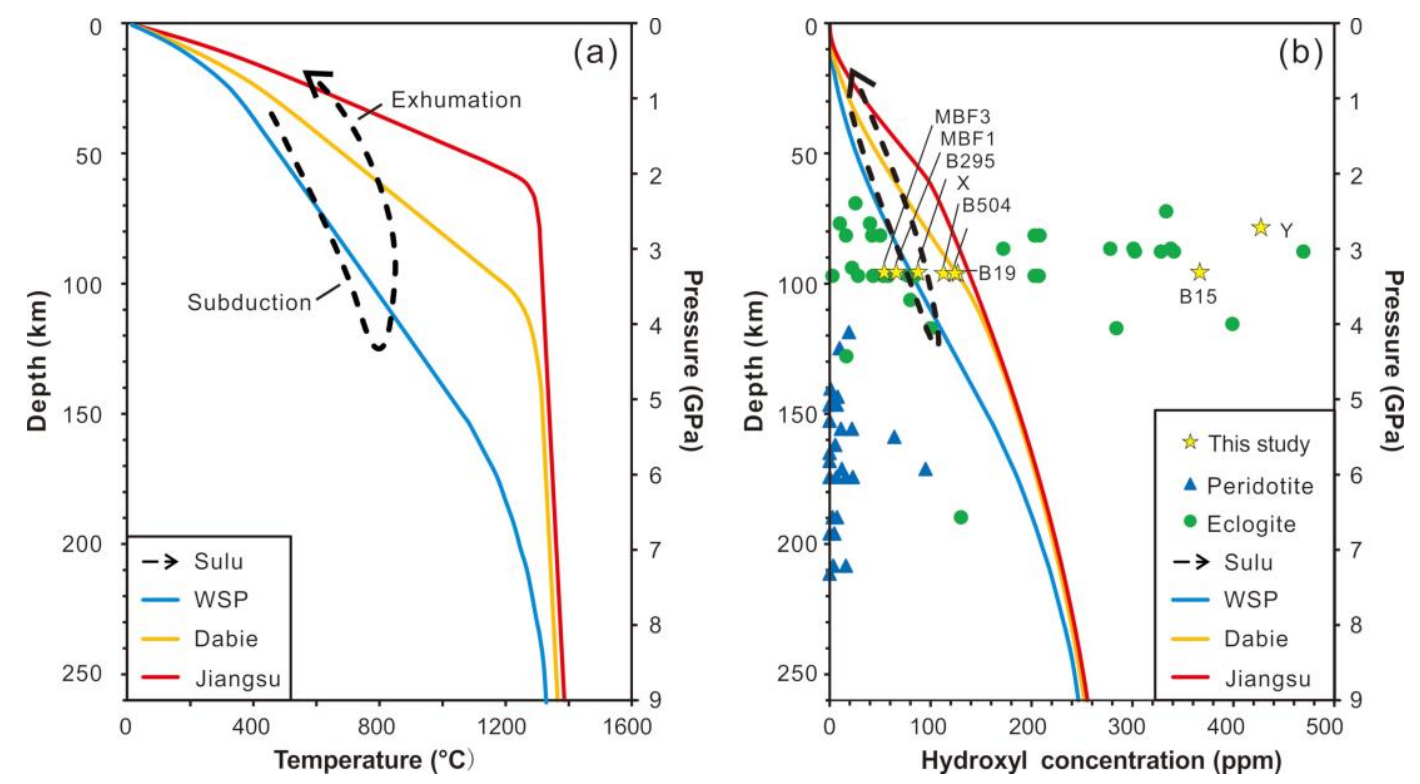

Figure 15. (a) Geotherms of the Sulu UHP belt [35], the Western Superior Province (WSP), the Dabie Mountains and the North Jiangsu basin [82]. (b) Hydroxyl concentration in garnet from eclogites in orogenic belts ([6,8-10,12-15,59]; this study) and from peridotites xenoliths from kimberlitic pipes [23-26]. Hydroxyl solubility in pyrope is calculated using Equation (6) and geothermal gradients in (a). The depth of the Sulu eclogites in this study is estimated using the minimum peak metamorphic pressure of $3.2 \mathrm{GPa}$.

Lu and Keppler [29] found that at Fe-FeO buffer conditions, water solubility in pyrope is only about $50 \%$ to $70 \%$ of the values with the $\mathrm{Ni}-\mathrm{NiO}$ buffer, demonstrating the important influence of oxygen fugacity on water solubility in garnet. For eclogites in UHP terranes, retrograde metamorphism has 
elevated $\mathrm{Fe}^{3+} / \Sigma \mathrm{Fe}$ ratios of eclogites because of oxidizing fluids during exhumation [83]. In contrast, peridotite xenoliths from kimberlite pipes were subjected to more reduced conditions at great depths [84], which will result in a smaller water solubility in garnet from the cratonic lithospheric mantle than from subduction zones. In addition, kimberlite magmas rise at a rate of $15-20 \mathrm{~km} / \mathrm{h}$ [85]. The extremely rapid transportation of peridotite xenoliths and megacrysts by kimberlite magmas will prevent effective hydrogen diffusion and alteration in garnet.

On the other hand, exhumation rates of UHP terranes vary from place to place and often include two stages: an initial fast exhumation from the mantle depth to $\sim 35 \mathrm{~km}$, and a slow exhumation from the lower crust to the upper crust. In average, the exhumation rates of UHP rocks are estimated to be $5-11.3 \mathrm{~mm} / \mathrm{yr}$ for the Dabie-Sulu orogenic belt [37], $\sim 10 \mathrm{~mm}$ for the Western Gneiss Region [86], $\sim 20 \mathrm{~mm} / \mathrm{yr}$ for the Kaghan Valley in the Himalayan orogen [87], and 16-50 mm/y for the Alpe Arami peridotites in the central Alps [88]. Decompressional dehydration of zoisite, phengite and lawsonite can supply enough aqueous fluid for water enrichment in omphacite and garnet during the initial exhumation [73]. The $n$ water-rich omphacite and garnet will experience decompressional dehydration and release D-depleted water during exhumation process [70]. Similar to anthophyllite exsolutions and clinochlore inclusions in garnet, nanometer-sized inclusions of clinochlore and amesite in omphacite from eclogites could also be formed during exhumation and result in overestimation of hydroxyl concentration in omphacite [33]. Hence, it is necessary to re-estimate the partition coefficient of hydrogen between garnet and omphacite in mantle conditions.

In addition, although hydroxyl concentration in one garnet grain may change greatly, there is no systematic change from the core to the rim in our garnet samples (Figure S1). Hydrogen diffusion in garnet includes bulk diffusion and grain boundary diffusion $[89,90]$. Experimental data show that the hydroxyl diffusion in garnet follows the Arrhenius relation [91]. The effect of hydrogen diffusion can be quantified by the diffusional length scale:

$$
l=\sqrt{D^{e f f} t}
$$

where $l$ is the characteristic distance in meter, $D^{\text {eff }}$ is the effective diffusion coefficient of garnet in $\mathrm{m}^{2} / \mathrm{s}$, and $t$ is time in second. We applied the linear diffusion model to calculate the diffusional length scale in garnet. When temperature is higher than $700{ }^{\circ} \mathrm{C}$, it takes less than $1 \mathrm{Ma}$ for hydrogen diffusing away from the garnet-rich area in a subduction zone (Figure 16a). When temperature is less than $700{ }^{\circ} \mathrm{C}$, the diffusion distance of hydrogen in garnet becomes very limited in a geological time scale. If using the sphere diffusion model [92], it will take 2 Ma for the loss of $50 \%$ hydrogen in garnet when temperature is less than $600{ }^{\circ} \mathrm{C}$ (Figure 16b). It is worthy emphasizing that when the surrounding rocks are also rich in $\mathrm{H}$, the $\mathrm{H}$ concentration gradient is rather favorable to a diffusion of $\mathrm{H}$ towards the garnet-rich area. This is the case in the late exhumation stage, as shown by incorporation of secondary fluid from hydrous minerals into garnet from retrograded eclogites.

Because the relatively low temperature and the rapid exhumation rate of UHP rocks in subduction channels at mantle depths (i.e., under eclogite facies metamorphism in the early exhumation stage), we propose that the critical temperature for the ignorable hydrogen diffusion in garnet is $600{ }^{\circ} \mathrm{C}$ in a geological time scale, corresponding to amphibolite facies retrograde metamorphism (Figure 15a). Hence the measured water content in garnet reflects in situ water concentration in garnet under amphibolite facies retrogression. Given wide stability conditions of garnet, the released water by both hydrous minerals (e.g., zoisite, phengite and lawsonite) and NAMs (omphacite and garnet) during retrograde metamorphism could be preserved in the crystal structure of garnet in different forms (hydroxyl in garnet and hydrous mineral inclusions, and molecular water in fluid inclusions). This will significantly decrease the viscosity of eclogites and facilitate their exhumation in a subduction channel $[16,17]$. The refore, garnet is an important candidate to transport water into the mantle transition zone and to carry water back from great depths to the shallow level through the subduction channel. 

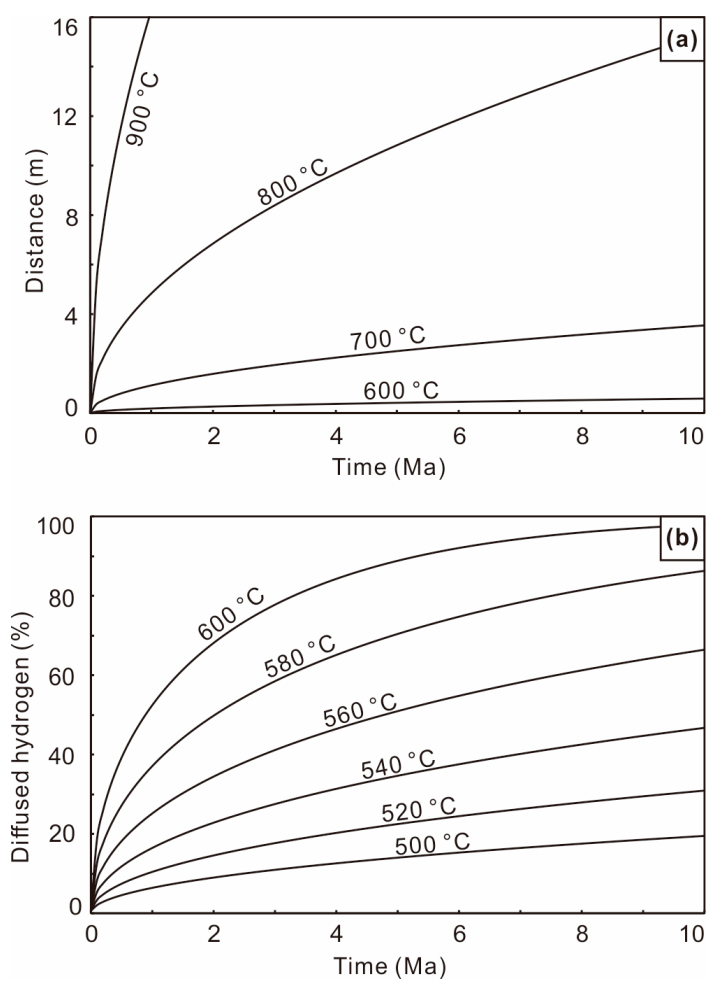

Figure 16. Calculated hydrogen diffusion in garnet. (a) The diffusional length scale of hydrogen in garnet under different temperatures using the linear diffusion model. (b) The percentage of the diffused hydrogen in an imaginary garnet crystal with a radius of one meter using the sphere diffusion model.

\section{Conclusions}

We measured the hydroxyl concentration in garnet from eight eclogite samples in the Sulu UHP terrane and the Sumdo HP metamorphic belt in China. Using Gaussian functions, IR spectra of garnet were fitted by three groups of broad bands and superimposed narrow bands. Hydroxyl concertation in garnet increases with the retrogression degree of eclogites from 54 to $427 \mathrm{ppm} \mathrm{H}_{2} \mathrm{O}$. The amount of primary structural water in garnet shows a positive correlation with $\mathrm{TiO}_{2}$ content for fresh and slightly retrograded UHP eclogites. Some narrow bands can be used to trace different substitution mechanisms of hydrogen due to the compositional change. TEM observations of water-rich domains in garnet reveal nanometer-sized anthophyllite exsolution lamellae, clinochlore inclusions, and pores within clinochlore inclusions. The broad band near $3400 \mathrm{~cm}^{-1}$ in garnet can be due to clusters of molecular water and chlorite inclusions, which will result in very high hydroxyl concentration in natural garnet.

The co-existence of water-poor garnet and hydrous anthophyllite in garnet with relatively small Si content suggests substitution of $\mathrm{SiO}_{4}{ }^{4-} \rightarrow(\mathrm{OH})_{4}{ }^{4-}$ in hydrous garnet at great depths, and formation of anthophyllite exsolutions by decomposition of hydrous garnet during exhumation. The extra water will be incorporated into clinochlore inclusions by reaction of anthophyllite with water, and then appear as clusters of molecular water in fluid inclusions. Heterogenous hydroxyl concentration in garnet $(<1$ to 2500 ppm $\mathrm{H}_{2} \mathrm{O}$ ) from eclogites recorded very limited fluid-rock interaction and the "frozen" water distribution during amphibolite facies retrograde metamorphism in subduction channels.

Supplementary Materials: The following are available online at http://www.mdpi.com/2075-163X/10/5/410/s1, Figure S1: Variations of the position of the group I band and hydroxyl concentration in garnet crystals; Figure S2: Correlation between chemical composition and hydroxyl concentration in garnet from fresh eclogite sample $\mathrm{X}$ and retrograded eclogite sample Y.

Author Contributions: Conceptualization, Y.G. and Q.W.; methodology, Y.G., Q.W., Y.L. and R.W.; software, Y.G.; validation, Y.G., Q.W., Y.L.; formal analysis, Y.G. and Y.L.; investigation, Y.G. and Y.L.; resources, Y.G., Q.W., Y.L. and R.W.; data curation, Y.G.; writing—original draft preparation, Y.G., Q.W.; writing—review and editing, 
Y.L. and R.W.; visualization, Y.G., and Y.L.; supervision, Q.W. and R.W.; project administration, Q.W.; funding acquisition, Q.W. All authors have read and agreed to the published version of the manuscript.

Funding: This research was supported by the National Natural Science Foundation of China (grants No. 41825006 and 41590623).

Acknowledgments: We thank Zhiqin Xu and Jingsui Yang for providing samples, and two anonymous reviewers for their constructive comments. Patience and support of academic editor Iwona Klonowska.

Conflicts of Interest: The authors declare there is no conflicts of interest regarding the publication of this paper.

\section{References}

1. Bell, D.; Rossman, G. Water in Earth's Mantle: The role of nominally anhydrous minerals. Science 1992, 255, 1391-1397. [CrossRef]

2. Libowitzky, E.; Beran, A. The structure of hydrous species in nominally anhydrous minerals: Information from polarized IR spectroscopy. Rev. Mineral. Geochem. 2006, 62, 29-52. [CrossRef]

3. Beran, A.; Libowitzky, E. Water in natural mantle minerals II: Olivine, garnet and accessory minerals. Rev. Mineral. Geochem. 2006, 62, 169-191. [CrossRef]

4. Peslier, A.H. A review of water contents of nominally anhydrous natural minerals in the mantles of Earth, Mars and the Moon. J. Volcanol. Geotherm. Res. 2010, 197, 239-258. [CrossRef]

5. Su, W.; You, Z.; Cong, B.; Ye, K.; Zhong, Z. Cluster of water molecules in garnet from ultrahigh-pressure eclogite. Geology 2002, 30, 611-614. [CrossRef]

6. Gong, B.; Chen, R.X.; Zheng, Y.F. Water contents and hydrogen isotopes in nominally anhydrous minerals from UHP metamorphic rocks in the Dabie-Sulu orogenic belt. Chin. Sci. Bull. 2013, 58, 4384-4389. [CrossRef]

7. Zheng, Y.F.; Chen, R.X.; Xu, Z.; Zhang, S.B. The transport of water in subduction zones. Sci. China Earth Sci. 2016, 59, 651-682. [CrossRef]

8. Katayama, I.; Nakashima, S.; Yurimoto, H. Water content in natural eclogite and implication for water transport into the deep upper mantle. Lithos 2006, 86, 245-259. [CrossRef]

9. Langer, K.; Robarick, E.; Sobolev, N.V.; Shatsky, V.S.; Wang, W.Y. Single-crystal spectra of garnets from diamondiferous high-pressure metamorphic rocks from Kazakhstan-Indications for $\mathrm{OH}^{-}, \mathrm{H}_{2} \mathrm{O}$, and FeTi charge-transfer. Eur. J. Mineral. 1993, 5, 1091-1100. [CrossRef]

10. Xia, Q.K.; Sheng, Y.M.; Yang, X.Z.; Yu, H.M. Heterogeneity of water in garnets from UHP eclogites, eastern Dabieshan, China. Chem. Geol. 2005, 224, 237-246. [CrossRef]

11. Chen, R.X.; Zheng, Y.F.; Gong, B.; Zhao, Z.F.; Gao, T.S.; Chen, B.; Wu, Y.B. Origin of retrograde fluid in ultrahigh-pressure metamorphic rocks: Constraints from mineral hydrogen isotope and water content changes in eclogite-gneiss transitions in the Sulu orogen. Geochim. Cosmochim. Acta 2007, 71, 2299-2325. [CrossRef]

12. Sheng, Y.M.; Xia, Q.K.; Yang, X.Z.; Hao, Y.T. $\mathrm{H}_{2} \mathrm{O}$ contents and D/H ratios of nominally anhydrous minerals from ultrahigh-pressure eclogites of the Dabie orogen, eastern China. Geochim. Cosmochim. Acta 2007, 71, 2079-2103. [CrossRef]

13. Liu, X.W.; Xie, Z.J.; Wang, L.; Xu, W.; Jin, Z.M. Water incorporation in garnets from ultrahigh pressure eclogites at Shuanghe, Dabieshan. Mineral. Mag. 2016, 80, 959-975. [CrossRef]

14. Schmädicke, E.; Gose, J. Water transport by subduction: Clues from garnet of Erzgebirge UHP eclogite. Am. Mineral. 2017, 102, 975-986. [CrossRef]

15. Gose, J.; Schmädicke, E. Water incorporation in garnet: Coesite versus quartz eclogite from Erzgebirge and Fichtelgebirge. J. Petrol. 2018, 59, 207-232. [CrossRef]

16. Xu, L.; Mei, S.; Dixon, N.; Jin, Z.; Suzuki, A.M.; Kohlstedt, D.L. Effect of water on rheological properties of garnet at high temperatures and pressures. Earth Planet. Sci. Lett. 2013, 379, 158-165. [CrossRef]

17. Xie, Z.; Liu, X.; Jin, Z. Effect of water on the dislocation mobility in garnet: Evidence from the Shuanghe UHP eclogites, Dabie orogen, China. Phys. Earth Planet. Inter. 2019, 293, 106273. [CrossRef]

18. Dai, L.; Li, H.; Hu, H.; Shan, S.M.; Jiang, J.; Hui, K. The effect of chemical composition and oxygen fugacity on the electrical conductivity of dry and hydrous garnet at high temperatures and pressures. Contrib. Mineral. Petrol. 2012, 163, 689-700. [CrossRef]

19. Zhang, B.; Li, B.; Zhao, C.; Yang, X. Large effect of water on Fe-Mg interdiffusion in garnet. Earth Planet. Sci. Lett. 2019, 505, 20-29. [CrossRef] 
20. Bell, D.R.; Rossman, G.R. The distribution of hydroxyl in garnets from the subcontinental mantle of southern Africa. Contrib. Mineral. Petrol. 1992, 111, 161-178. [CrossRef]

21. Snyder, G.A.; Taylor, L.A.; Jerde, E.A.; Clayton, R.N.; Mayeda, T.K.; Deines, P.; Rossman, G.R.; Sobolev, N.V. Archean mantle heterogeneity and the origin of diamondiferous eclogites, Siberia-Evidence from stable isotopes and hydroxyl in garnet. Am. Mineral. 1995, 80, 799-809. [CrossRef]

22. Matsyuk, S.S.; Langer, K.; Hosch, A. Hydroxyl defects in garnets from mantle xenoliths in kimberlites of the Siberian platform. Contrib. Mineral. Petrol. 1998, 132, 163-179. [CrossRef]

23. Peslier, A.H.; Woodland, A.B.; Bell, D.R.; Lazarov, M.; Lapen, T.J. Metasomatic control of water contents in the Kaapvaal cratonic mantle. Geochim. Cosmochim. Acta 2012, 97, 213-246. [CrossRef]

24. Doucet, L.S.; Peslier, A.H.; Ionov, D.A.; Brandon, A.D.; Golovin, A.V.; Goncharov, A.G.; Ashchepkov, I.V. High water contents in the Siberian cratonic mantle linked to metasomatism: An FTIR study of Udachnaya peridotite xenoliths. Geochim. Cosmochim. Acta 2014, 137, 159-187. [CrossRef]

25. Ragozin, A.L.; Karimova, A.A.; Litasov, K.D.; Zedgenizov, D.A.; Shatsky, V.S. Water content in minerals of mantle xenoliths from the Udachnaya pipe kimberlites (Yakutia). Russ. Geol. Geophys. 2014, 55, 428-442. [CrossRef]

26. Schmädicke, E.; Gose, J.; Reinhardt, J.; Will, T.M.; Stalder, R. Garnet in cratonic and non-cratonic mantle and lower crustal xenoliths from southern Africa: Composition, water incorporation and geodynamic constraints. Precambrian Res. 2015, 270, 285-299. [CrossRef]

27. Bell, D.R.; Rossman, G.R.; Moore, R.O. Abundance and partitioning of $\mathrm{OH}$ in a high-pressure magmatic system: Megacrysts from the Monastery kimberlite, South Africa. J. Petrol. 2004, 45, 1539-1564. [CrossRef]

28. Mookherjee, M.; Karato, S. Solubility of water in pyrope-rich garnet at high pressures and temperature. Geophys. Res. Lett. 2010, 37, L03310. [CrossRef]

29. Lu, R.; Keppler, H. Water solubility in pyrope to 100 kbar. Contrib. Mineral. Petrol. 1997, 129, 35-42. [CrossRef]

30. Withers, A.C.; Wood, B.J.; Carroll, M.R. The OH content of pyrope at high pressure. Chem. Geol. 1998, 147, 161-171. [CrossRef]

31. Miller, G.; Rossman, G.; Harlow, G. The natural occurrence of hydroxide in olivine. Phys. Chem. Miner. 1987, 14, 461-472. [CrossRef]

32. Jung, H.; Lee, J.; Ko, B.; Jung, S.; Park, M.; Cao, Y.; Song, S. Natural type-C olivine fabrics in garnet peridotites in North Qaidam UHP collision belt, NW China. Tectonophysics 2013, 594, 91-102. [CrossRef]

33. Koch-Müller, M.; Matsyuk, S.; Wirth, R. Hydroxyl in omphacites and omphacitic clinopyoxenes of upper mantle to lower crustal origin beneath the Siberian platform. Am. Mineral. 2004, 89, 921-931. [CrossRef]

34. Song, S.G.; Zhang, L.F.; Chen, J.; Liou, J.G.; Niu, Y.N. Sodic amphibole exsolutions in garnet from garnet-peridotite, North Qaidam UHPM belt, NW China: Implications for ultradeep-origin and hydroxyl defects in mantle garnets. Am. Mineral. 2005, 90, 814-820. [CrossRef]

35. Zheng, Y.F. A perspective view on ultrahigh-pressure metamorphism and continental collision in the Dabie-Sulu orogenic belt. Chin. Sci. Bull. 2008, 53, 3081-3104. [CrossRef]

36. Zhang, Z.M.; Shen, K.; Wang, J.L.; Dong, H.L. Petrological and geochronological constraints on the formation, subduction and exhumation of the continental crust in the southern Sulu orogen, eastern-central China. Tectonophysics 2009, 475, 291-307. [CrossRef]

37. Liu, F.L.; Liou, J.G. Zircon as the best mineral for P-T-time history of UHP metamorphism: A review on mineral inclusions and U-Pb SHRIMP ages of zircons from the Dabie-Sulu UHP rocks. J. Asian Earth Sci. 2011, 40, 1-39. [CrossRef]

38. Yang, J.; Xu, Z.; Li, Z.; Xua, X.; Li, T.; Ren, Y.; Li, H.; Chen, S.; Robinson, P.T. Discovery of an eclogite belt in the Lhasa block, Tibet: A new border for Paleo-Tethys? J. Asian Earth Sci. 2009, 34, 76-89. [CrossRef]

39. Zeng, L.; Liu, J.; Gao, L.; Chen, F.; Xie, K. Early Mesozoic high-pressure metamorphism within the Lhasa Block, Tibet and its implications for regional tectonics. Earth Sci. Front. 2009, 16, 140-151. [CrossRef]

40. Zhang, C.; Bader, T.; Van Roermund, H.L.M.; Yang, J.S.; Shen, T.T.; Qiu, T.; Li, P. The metamorphic evolution and tectonic significance of the Sumdo HP-UHP metamorphic terrane, central-south Lhasa Block, Tibet. In HP-UHP Metamorphism and Tectonic Evolution of Orogenic Belts; Zhang, L., Zhang, Z., Schertl, H.P., Wei, C., Eds.; Geological Society of London, Special Publication: London, UK, 2018; Volume 474, pp. 209-229.

41. Whitney, D.L.; Evans, B.W. Abbreviations for names of rock-forming minerals. Am. Mineral. 2010, 95, 185-187. [CrossRef] 
42. Bell, D.R.; Ihinger, P.D.; Rossman, G.R. Quantitative-analysis of trace $\mathrm{OH}$ in garnet and pyroxenes. Am. Mineral. 1995, 80, 465-474. [CrossRef]

43. Wojdyr, M. Fityk: A general-purpose peak fitting program. J. Appl. Crystallogr. 2010, 43, 1126-1128. [CrossRef]

44. Rossman, G.R.; Aines, R.D. The hydrous components in garnets: Grossular-hydrogrossular. Am. Mineral. 1991, 76, 1153-1164.

45. Wirth, R. Focused Ion Beam (FIB) combined with SEM and TEM: Advanced analytical tools for studies of chemical composition, microstructure and crystal structure in geomaterials on a nanometre scale. Chem. Geol. 2009, 261, 217-229. [CrossRef]

46. Aines, R.D.; Rossman, G.R. The hydrous component in garnets-Pyralspites. Am. Mineral. 1984, 69, $1116-1126$.

47. Birkett, T.C.; Trzcienski, W.E. Hydrogarnet-Multi-site hydrogen occupancy in the garnet structure. Can. Mineral. 1984, 22, 675-680.

48. Beran, A.; Langer, K.; Andrut, M. Single-crystal infrared-spectra in the range of OH fundamentals of paragenetic garnet, omphacite and kyanite in an eclogitic mantle xenolith. Mineral. Petrol. 1993, 48, 257-268. [CrossRef]

49. Wirth, R. Water in minerals detectable by electron energy-loss spectroscopy EELS. Phys. Chem. Miner. 1997, 24, 561-568. [CrossRef]

50. Wirth, R.; Wunder, B. Characterization of OH-containing phases by TEM using electron energy-loss spectroscopy (EELS): Clinohumite-OH, chondrodite-OH, phase A and the (F,OH)-solid solution series of topaz. J. Trace Microprobe Tech. 2000, 18, 35-49.

51. Cohen-Addad, C.; Ducros, P.; Bertaut, E.F. Etude de la substitution du groupement $\mathrm{SiO}_{4}$ par $(\mathrm{OH})_{4}$ dans les composés $\mathrm{Al}_{2} \mathrm{Ca}_{3}(\mathrm{OH})_{12}$ et $\mathrm{A}_{12} \mathrm{Ca}_{3}(\mathrm{SiO})_{2,16}(\mathrm{OH})_{3,36}$ de type grenat. Acta Crystallogr. 1967, $23,220$. [CrossRef]

52. Lager, G.A.; Armbruster, T.; Rotella, F.J.; Rossman, G.R. OH substitution in garnets-X-ray and neutrondiffraction, infrared, and geometric-modeling studies. Am. Mineral. 1989, 74, 840-851.

53. Lager, G.A.; Von Dreele, R.B. Neutron powder diffraction study of hydrogarnet to 9.0 GPa. Am. Mineral. 1996, 81, 1097-1104. [CrossRef]

54. Harmon, K.M.; Gabriele, J.M.; Nuttall, A.S. Hydrogen-bonding. 14. Hydrogen-bonding in the tetrahedral $\mathrm{O}_{4} \mathrm{H}_{4}{ }^{4-}$ cluster in hydrogrossular. J. Mol. Struct. 1982, 82, 213-219. [CrossRef]

55. Rossman, G.R.; Beran, A.; Langer, K. The hydrous component of pyrope from the Dora Maira massif, western Alps. Eur. J. Mineral. 1989, 1, 151-154. [CrossRef]

56. Khomenko, V.M.; Langer, K.; Beran, A.; Kochmuller, M.; Fehr, T. Titanium substitution and OH-bearing defects in hydrothermally grown pyrope crystals. Phys. Chem. Miner. 1994, 20, 483-488. [CrossRef]

57. Armbruster, T.; Birrer, J.; Libowitzky, E.; Beran, A. Crystal chemistry of Ti-bearing andradites. Eur. J. Mineral. 1998, 10, 907-921. [CrossRef]

58. Li, H.Y.; Chen, R.X.; Zheng, Y.F.; Hu, Z. Water in garnet pyroxenite from the Sulu orogen: Implications for crust-mantle interaction in continental subduction zone. Chem. Geol. 2018, 478, 18-38. [CrossRef]

59. Xu, W.; Liu, X.W.; Jin, Z.M. Water in UHP eclogites at CCSD: FTIR analysis. J. China Univ. Geosci. 2006, 31, 830-838.

60. Thompson, E.C.; Campbell, A.J.; Liu, Z. In -situ infrared spectroscopic studies of hydroxyl in amphiboles at high pressure. Am. Mineral. 2016, 101, 706-712. [CrossRef]

61. Ackermann, L.; Cemič, L.; Langer, K. Hydrogarnet substitution in pyrope: A possible location for "water" in the mantle. Earth Planet. Sci. Lett. 1983, 62, 208-214. [CrossRef]

62. Lafuente, B.; Downs, R.T.; Yang, H.; Stone, N. The power of databases: The RRUFF project. In Highlights in Mineralogical Crystallography; Armbruster, T., Danisi, R.M., Eds.; W. De Gruyter: Berlin, Germany, 2015; pp. 1-30.

63. Prieto, A.C.; Dubessy, J.; Cathelineau, M. Structure-composition relationships in trioctahedral chlorites: A vibrational spectroscopy study. Clays Clay Miner. 1991, 39, 531-539. [CrossRef]

64. Yang, M.; Ye, M.; Han, H.; Ren, G.; Han, L.; Zhang, Z. Near-infrared spectroscopic study of chlorite minerals. J. Spectrosc. 2018, 2018, 6958260. [CrossRef]

65. Gong, B.; Zheng, Y.-F.; Chen, R.-X. TC/EA-MS online determination of hydrogen isotope composition and water concentration in eclogitic garnet. Phys. Chem. Miner. 2007, 34, 687-698. [CrossRef]

66. Zhang, Y.X. $\mathrm{H}_{2} \mathrm{O}$ in rhyolitic glasses and melts: Measurement, speciation, solubility, and diffusion. Rev. Geophys. 1999, 37, 493-516. [CrossRef] 
67. Okumura, S.; Nakashima, S. Water diffusion in basaltic to dacitic glasses. Chem. Geol. 2006, 227, 70-82. [CrossRef]

68. Ni, H.; Liu, Y.; Wang, L.; Zhang, Y. Water speciation and diffusion in haploandesitic melts at $743-873 \mathrm{~K}$ and 100 MPa. Geochim. Cosmochim. Acta 2009, 73, 3630-3641. [CrossRef]

69. Mconie, A.W.; Fawcett, J.J.; James, R.S. The stability of intermediate chlorites of the clinochlore-daphnite series at 2 kbar $\mathrm{PH}_{2} \mathrm{O}$. Am. Mineral. 1975, 60, 1047-1062.

70. Chen, R.X.; Zheng, Y.F.; Gong, B. Mineral hydrogen isotopes and water contents in ultrahigh-pressure metabasite and metagranite: Constraints on fluid flow during continental subduction-zone metamorphism. Chem. Geol. 2011, 281, 103-124. [CrossRef]

71. Fu, B.; Touret, J.L.R.; Zheng, Y.F. Remnants of premetamorphic fluid and oxygen isotopic signatures in eclogites and garnet clinopyroxenite from the Dabie-Sulu terranes, eastern China. J. Metamorph. Geol. 2003, 21, 561-578. [CrossRef]

72. Zhang, Z.M.; Shen, K.; Xiao, Y.L.; Van Den Kerkhof, A.M.; Hoefs, J.; Liou, J.G. Fluid composition and evolution attending UHP metamorphism: Study of fluid inclusions from drill cores, southern Sulu belt, eastern China. Int. Geol. Rev. 2005, 47, 297-309. [CrossRef]

73. Zheng, Y.F. Fluid regime in continental subduction zones: Petrological insights from ultrahigh-pressure metamorphic rocks. J. Geol. Soc. 2009, 166, 763-782. [CrossRef]

74. Suzuoki, T.; Epstein, S. Hydrogen isotope fractionation between OH-bearing minerals and water. Geochim. Cosmochim. Acta 1976, 40, 1229-1240. [CrossRef]

75. Graham, C.M.; Sheppard, S.M.F.; Heaton, T.H.E. Experimental hydrogen isotope studies, I. Systematics of hydrogen isotope fractionation in the systems epidote- $\mathrm{H}_{2} \mathrm{O}$, zoisite- $\mathrm{H}_{2} \mathrm{O}$ and $\mathrm{AlO}(\mathrm{OH})-\mathrm{H}_{2} \mathrm{O}$. Geochim. Cosmochim. Acta 1980, 44, 353-364. [CrossRef]

76. Graham, C.M.; Harmon, R.S.; Sheppard, S.M.F. Experimental hydrogen isotope studies: Hydrogen isotope exchange between amphibole and water. Am. Mineral. 1984, 69, 128-138.

77. $\mathrm{Xu}, \mathrm{H} . J . ; \mathrm{Wu}, \mathrm{Y}$. Oriented inclusions of pyroxene, amphibole and rutile in garnet from the Lüliangshan garnet peridotite massif, North Qaidam UHPM belt, NW China: An electron backscatter diffraction study. J. Metamorph. Geol. 2017, 35, 1-17. [CrossRef]

78. Sakamaki, K.; Sato, Y.; Ogasawara, Y. Hydrous Na-garnet from Garnet Ridge; products of mantle metasomatism underneath the Colorado Plateau. Prog. Earth Planet. Sci. 2016, 3, 3-20. [CrossRef]

79. Liu, F.; Xu, Z.; Liou, J.G.; Dong, H.; Xue, H. Ultrahigh-pressure mineral assemblages in zircons from the surface to $5158 \mathrm{~m}$ depth in cores of the main drill hole, Chinese Continental Scientific Drilling Project, southwestern Sulu belt, China. Int. Geol. Rev. 2007, 49, 454-478. [CrossRef]

80. Sterner, S.M.; Pitzer, K.S. An equation of state for carbon-dioxide valid from zero to extreme pressure. Contrib. Mineral. Petrol. 1994, 117, 362-374. [CrossRef]

81. Pitzer, K.S.; Sterner, S.M. Equations of state valid continuously from zero to extreme pressures with $\mathrm{H}_{2} \mathrm{O}$ and $\mathrm{CO}_{2}$ as examples. Int. J. The rmophys. 1995, 16, 511-518. [CrossRef]

82. Wang, Q. A review of water contents and ductile deformation mechanisms of olivine: Implications for the lithosphere-asthenosphere boundary of continents. Lithos 2010, 120, 30-41. [CrossRef]

83. Li, D.Y.; Xiao, Y.L.; Li, W.Y.; Zhu, X.; Williams, H.M.; Li, Y.L. Iron isotopic systematics of UHP eclogites respond to oxidizing fluid during exhumation. J. Metamorph. Geol. 2016, 34, 987-997. [CrossRef]

84. Goncharov, A.G.; Ionov, D.A.; Doucet, L.S.; Pokhilenko, L.N. The rmal state, oxygen fugacity and C-O-H fluid speciation in cratonic lithospheric mantle: New data on peridotite xenoliths from the Udachnaya kimberlite, Siberia. Earth Planet. Sci. Lett. 2012, 357-358, 99-110. [CrossRef]

85. Peslier, A.H.; Woodland, A.B.; Wolff, J.A. Fast kimberlite ascent rates estimated from hydrogen diffusion profiles in xenolithic mantle olivines from southern Africa. Geochim. Cosmochim. Acta 2008, 72, 2711-2722. [CrossRef]

86. Carswell, D.A.; Brueckner, H.K.; Cuthbert, S.J.; Mehta, K.; O'Brien, P.J. The timing of stabilisation and the exhumation rate for ultrahigh-pressure rocks in the Western Gneiss Region of Norway. J. Metamorph. Geol. 2003, 21, 601-612. [CrossRef]

87. O’Brien, P.J.; Zotov, N.; Law, R.; Khan, M.A.; Jan, M.Q. Coesite in Himalayan eclogite and implications for models of India-Asia collision. Geology 2001, 29, 435-438. [CrossRef] 
88. Olker, B.; Altherr, R.; Paquin, J. Fast exhumation of the ultrahigh-pressure Alpe Arami garnet peridotite (Central Alps, Switzerland): Constraints from geospeedometry and thermal modelling. J. Metamorph. Geol. 2003, 21, 395-402. [CrossRef]

89. Chakraborty, S. Diffusion in solid silicates: A tool to track timescales of processes comes of age. Annu. Rev. Earth Planet. Sci. 2008, 36, 153-190. [CrossRef]

90. Zhang, B. An overview of Fe-Mg interdiffusion in mantle minerals. Surv. Geophys. 2017, 38, 727-755. [CrossRef]

91. Wang, L.P.; Zhang, Y.X.; Essene, E.J. Diffusion of the hydrous component in pyrope. Am. Mineral. 1996, 81, 706-718. [CrossRef]

92. Crank, J. The Mathematics of Diffusion, 2nd ed.; Oxford University Press: Oxford, UK, 1975.

(C) 2020 by the authors. Licensee MDPI, Basel, Switzerland. This article is an open access article distributed under the terms and conditions of the Creative Commons Attribution (CC BY) license (http://creativecommons.org/licenses/by/4.0/). 